NBER WORKING PAPER SERIES

\title{
CAUSES OF THE GREAT RECESSION OF 2007-9: THE FINANCIAL CRISIS IS THE SYMPTOM NOT THE DISEASE!
}

\author{
Ravi Jagannathan \\ Mudit Kapoor \\ Ernst Schaumburg \\ Working Paper 15404 \\ http://www.nber.org/papers/w15404
}

\author{
NATIONAL BUREAU OF ECONOMIC RESEARCH \\ 1050 Massachusetts Avenue \\ Cambridge, MA 02138 \\ October 2009
}

We would like to thank Sumit Agarwal, John Boyd, Chun Chang, Darrell Duffie, Martin Eichenbaum, Andrei Jirnyi, Arvind Krishnamurthy, Srikant Marakani, Jonathan Parker, George Pennacchi, Ashwin Ravikumar, Shamika Ravi, Sergio Rebelo, Mike Sher, and Vefa Tarhan for helpful discussions; Maurice Obsfeldt, Andrei Shleifer, Pedro Paulo Bartolomei da Silveira, Mark Stohs, and seminar participants at the Indian School of Business, Cass Business School, Singapore Management University, National University of Singapore, Chicago Mercantile Exchange, University of Michigan, University of Toronto, University of Colorado, University of Massachussets, University of Oklahoma, University of Texas at Dallas, FIRS Florence Conference, Western Finance Association Meeting in Victoria, Canada, AFA International Conference in Hong Kong, and NBER Chinese Economy Working Group Meeting for helpful comments; Charles Engel for pointing out an error in an earlier version of the paper; and Athreya Sampath for excellent research assistance. All remaining errors are our own. The views expressed in this paper are those of the authors and do not represent the views of the institutions to which they belong.

NBER working papers are circulated for discussion and comment purposes. They have not been peerreviewed or been subject to the review by the NBER Board of Directors that accompanies official NBER publications.

(C) 2009 by Ravi Jagannathan, Mudit Kapoor, and Ernst Schaumburg. All rights reserved. Short sections of text, not to exceed two paragraphs, may be quoted without explicit permission provided that full credit, including $\odot$ notice, is given to the source. 
Causes of the Great Recession of 2007-9: The Financial Crisis is the Symptom not the Disease! Ravi Jagannathan, Mudit Kapoor, and Ernst Schaumburg

NBER Working Paper No. 15404

October 2009

JEL No. E0,E00,E2,E3,G0,G00,G01,G2

\author{
$\underline{\text { ABSTRACT }}$ \\ Globalization has made it possible for labor in developing countries to augment labor in the developed \\ world, without having to relocate, in ways not thought possible only a few decades ago. We argue \\ that this large increase in the developed world's effective labor supply, triggered by geo-political events \\ and technological innovations, coupled with the inability of existing institutions in the US and developing \\ nations themselves to cope with this shock set the stage for the great recession. The financial crisis \\ in the US was but the first acute symptom. \\ Ravi Jagannathan \\ Kellogg Graduate School of Management \\ Northwestern University \\ 2001 Sheridan Road \\ Leverone/Anderson Complex \\ Evanston, IL 60208-2001 \\ and NBER \\ rjaganna@northwestern.edu \\ Mudit Kapoor \\ Indian School of Business \\ Gachibowli \\ Hyderabad - 500032 \\ India \\ mudit_kapoor@isb.edu \\ Ernst Schaumburg \\ Federal Reserve Bank of New York \\ 33 Liberty Street \\ New York, NY 10045 \\ ernst.schaumburg@ny.frb.org
}




\section{Contents}

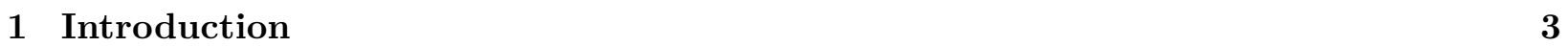

2 The Emergence of China, Labor Supply Shock, Current Account Deficit, and Capital Flows $\quad 6$

2.1 Labor Supply Shock, Local Employment, Wages, and Savings . . . . . . . . . . . . 6

2.2 Current Account Deficits and Capital Flows into the US Housing Market $\ldots . . .9$

3 US households $\quad 13$

$3.1 \quad$ A Stylized Model of Households' Consumption Choice . . . . . . . . . . . . . . . . 17

4 House Prices and the Current Account Balance 20

4.1 The Role of Financial Engineering . . . . . . . . . . . . . . . . . 23

4.2 The Role of the Government $\ldots \ldots \ldots \ldots \ldots \ldots$. . . . . . . . . . . . 25

4.3 Why Did the Bubble Burst? . . . . . . . . . . . . . . . . . . 27

5 Why Housing Bubbles are Different 29

5.1 Money Channeled into Housing has a Bigger Price Effect . . . . . . . . . . . . . . 29

5.2 A Housing Bubble is Different from a Stock Market Bubble . . . . . . . . . . . . . . 30

5.3 The US is not Alone: Some International Evidence . . . . . . . . . . . . . . . . . . 32

$\begin{array}{lll}6 & \text { Conclusion } & 32\end{array}$

\begin{tabular}{|ll}
\hline A Tables & 37
\end{tabular} 


\section{Introduction}

The global recession of 2007-9 was without a doubt the most severe since the great depression of the 1930s. A large part of the wealth of US households evaporated: Household net worth in the US (including nonprofit organizations) went from $\$ 42.1$ trillion $(4.4 \times \mathrm{GDP})$ in 1999 to $\$ 51.7$ trillion $(3.6 \times \mathrm{GDP})$ in 2008 while the consumer price index (CPI) increased by $29 \%$, and the number of households in the US increased to 117 million from 104 million.1 As a result, the net worth per household in real terms (1999 dollars) declined sharply from $\$ 402,000$ to $\$ 343,000$, a $15 \%$ drop. The unemployment rate captures the difficult times of the average citizen even better: it went up from $4.4 \%$ in 1999 to $7.2 \%$ in 2008 - and peaked at $10.1 \%$ in October 2009, even as discouraged workers increasingly dropped out of the workforce and no longer counted in the unemployment statistics.

In what follows we provide an explanation for a recession of this magnitude. We make the case that a huge and rapid increase in the developed world's effective labor supply, triggered by the globalization of emerging economies in conjunction with innovations in information technology and transportation, is the major underlying force that is affecting world economic events today. In essence, the productive citizens of less developed countries have effectively joined the workforce of developed countries in increasing numbers, without the need to change their citizenship or relocate. The global macroeconomic adjustments required to absorb this massive labor supply shock and return the world economy to its new long term equilibrium are still taking place. The global financial crisis of 2007-9 and the ensuing great recession can be viewed as side-effects of this adjustment process caused by the inability of existing financial and legal institutions in the US and abroad to cope with the events set off by this force: The inability of emerging economies to absorb savings through domestic investment and consumption due to inadequate national financial markets; the inability of exchange rates to act as shock absorbers due to capital controls motivated by immediate national objectives; the inability of the US economy to adjust to the perverse incentives caused by huge moneys inflow leading to a breakdown of checks and balances at various financial institution, 2 ,

Is seems clear that no single general equilibrium model can hope to adequately capture all the first order important strategic, financial and open economy aspects necessary to study the roots of the great recession 3 For this reason, we will resort to an informal model of the players in the global economy as sketched in the diagram below. In particular, our analysis focuses squarely on the two main actors, China and US households, whose growing economic and financial interdependence has been a key feature of global developments over the last two decades. Almost every arrow connecting these two actors and their intermediaries in the diagram below has been examined in the recent finance and international economics literatures. However, to our knowledge, this literature always

\footnotetext{
${ }^{1}$ Table F.100 of the Flow of Funds, http://www.federalreserve.gov/releases/z1/Current/z1r-3.pdf

${ }^{2}$ The evidence in Sussman \& Yafeh (2011) is consistent with the view that macro global events played a major role in precipitating the financial crisis

${ }^{3}$ In typical equilibrium trade models that examine outsourcing, the poor country will be borrowing from the rich country and running a current account deficit whereas in fact China is one of the largest lenders to the US.
} 
focusing exclusively on a few individual linkages and not the complete picture. The contribution of this paper is therefore to put together the many individual insights from these distinct literatures to tell a coherent story of why the financial crisis arose in the way it did, when it did and where we stand with respect to the ultimate adjustments that must yet take place.

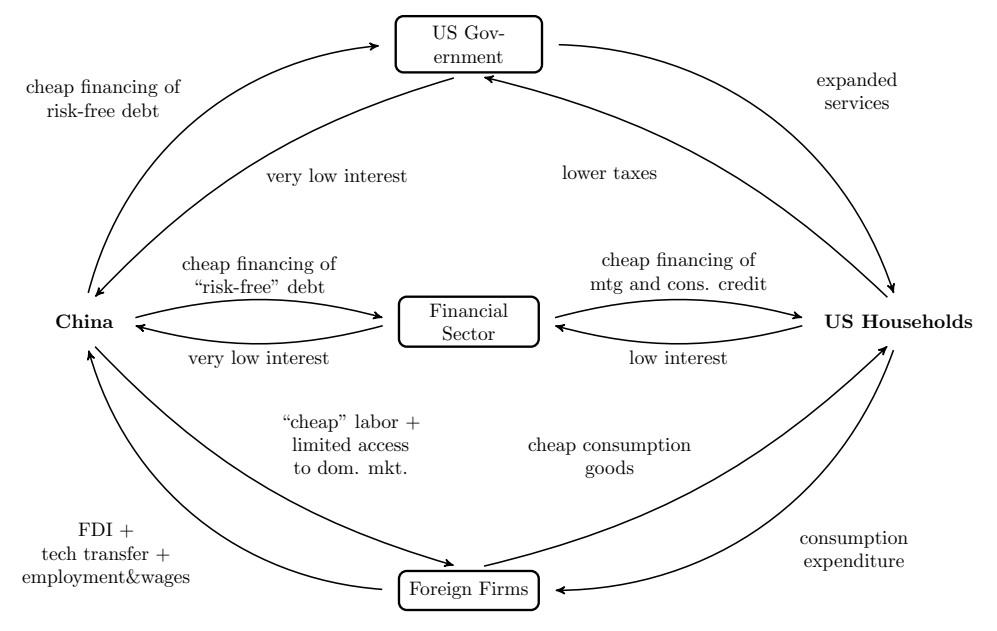

Figure 1: Our simplified model of the events leading up to the crisis of 2007-9.

In our starkly simplified model of the world leading up to the crisis of 2007-9 (sketched in Figure 1), we trace the genesis of the global macroeconomic imbalances back to a huge labor supply increase associated with the gradual opening up of China in the decades following the normalization of relations with the US in 1979 In a nutshell, China pursued an export led growth strategy based on attracting foreign direct investment and technology in return for foreign firms' access to low cost labor (the lower left set of arrows), as explained by Dooley, Folkerts-Landau \& Garber (2007). The Chinese labor cost advantage (in USD terms) is maintained through tight control of domestic wage inflation and a low USD/RMB exchange rate peg enforced through a system of tight capital controls. The period of high FDI inflows during the initial development of China's export sector is followed by an extended period of large Chinese current account surpluses as the transfer of know-how is completed and homegrown exporters appear. The Chinese current account surplus is matched by offsetting fund inflows into US fixed income markets, driving down interest rates (the upper left sets of arrows). This pattern of capital flows from the developing word to industrialized countries has been described by some authors as the "Global Savings Glut", and the causality from excess savings abroad to lower US interest rates has been well studied in the literature (see, for example Bernanke (2005)). One immediate beneficiary is the US government which is able to roll-over the existing stock of government debt, expand services while taxing households less and run up the deficit without suffering higher interest rates (the top right set of arrows). The

\footnotetext{
${ }^{4}$ Although we focus our story on China (by far the larger shock), it should be noted that the fall of the Soviet Union, which a decade later ended the cold war, helped the developing world as a whole focus more on economic growth based on trade with the Western world.
} 
inflow of foreign capital directed at "risk-free" investments and investors "reaching for yield" also puts downwards pressure on rates on close substitute AAA rated securities (the middle left set of arrows). The excess demand for ultra safe fixed income securities in turn leads to a spurt of innovation in the financial sector which engineers ever increasing amounts of AAA rated structured products backed by mortgages and consumer credit (the middle right set of arrows). The flow of foreign capital is thus ultimately channeled into the US real estate market and cheap consumer loans, giving the illusion of wealth and setting the stage for a housing price bubble. US households, feeling wealthy in an environment with low taxes, expanded government services, cheap credit, cheap consumption goods and seemingly ever increasing home prices, go on a consumption binge and let the personal savings rate drop below $2 \%$ for the first time since the Great Depression (lower right set of arrows). A non-trivial portion of the US household consumption expenditure goes to retail chains like Walmart and Home Depot and other firms which employ a large number of US workers but (indirectly) an even larger number of Chinese workers in China's export sector, thus closing the circle. As long as China is able to control domestic wages and remains willing to finance ever larger US deficits on the cheap in return for technology transfer and increased employment, this cycle can in principle go on in perpetuity. In the "textbook" treatment of persistent current account imbalances and currency crises, however, the Chinese currency peg cannot be defended indefinitely and eventually "hot money" flowing back into China in circumvention of the capital controls will lead to high inflationary pressures and eventually force China to give up its peg, as pointed out by Dooley, Folkerts-Landau \& Garber (2007). This sequence of events has not played out as of this writing. Instead the weaker link turned out to be US and global financial markets which turned out to be surprisingly vulnerable when the housing bubble finally burst.

The remainder of the paper is structured as follows. In Section 2, we briefly review the emergence of China on the global economic scene and the associated changes in global capital flows. In section 3 we discuss how housing price bubble that was created by foreign inflows led to a consumption binge by US households due to the wealth effect (a significant fraction of which is spent on imports). In Section 4 we provide further evidence linking the current account balance of the US and to the funds flow into the US mortgage market. We also discuss the role of financial engineering by summarizing the salient facts from the vast financial crisis literature on distortion of incentives and the failures of checks and balances that brought the world financial system to its knees. In Section 5 we argue that housing bubbles are different than stock market bubbles in terms of their real effects on the economy. We conclude our analysis in Section 6 with our views on the future adjustments still facing the US and lessons learned. 


\section{The Emergence of China, Labor Supply Shock, Current Ac- count Deficit, and Capital Flows}

China has arguably benefited greatly from globalization and has emerged as one of the most important creditor nations and trading partners of the US 5 In 1980, China accounted for less than $2 \%$ of world GDP. By 2007 this figure had grown to almost $6 \%$ (or 12\% when adjusted for purchasing power parity), making China the third largest economy on track to overtaking Japan as the second largest economy by 2011.This meteoric rise is the result of a systematic policy of industrialization and has been greatly facilitated by innovations in communications and transportation technology that have brought the services of China's enormous pool of underemployed labor on-line for western consumers and corporations.

To put things in context, the size of the increase in the developed world's effective labor supply is of a similar order of magnitude as the increase in the western world's access to land and natural resources following the discovery of the Americas. A shock of such a magnitude to the developed world's labor supply is likely to adversely affect some and positively affect others in the short run, even if everyone hypothetically could be made better off in the long run. Those in the emerging economies who now have new opportunities will flourish. A significant fraction of those in the western world who remain employed will benefit and see their wages go up while others will see their jobs vanish. Although the wages of a significant fraction of the population in the western world could be adversely affected in the short run, this effect will be partially offset by the availability of cheaper consumption goods.

\subsection{Labor Supply Shock, Local Employment, Wages, and Savings}

Until 1979 China was entirely closed to foreign investors. Over the following 12 years, a series of reforms initiated by Deng Xiaopeng gradually sought to bring China's large masses of underemployed labor into the manufacturing and industrial sectors of the world economy. This plan was in no small measure made possible by recent innovations in transportation technology, such as the standardization of container shipping in the early 1970's, that made a vast variety of goods cost effective to ship around the world. Facing the limitations of domestic capital markets and the lack of technological know-how to build up a home grown export sector, China's initial strategy depended on allowing foreign firms into a very limited number of sectors where domestic state owned enterprises were not active or those where China wanted to acquire technological know-how (see e.g. Graham \& Wada (2002)). As seen from Figure 2, FDI flows initially remained fairly modest (less than 1\% of GDP) until 1991.

In 1992, China devalued the Yuan by more than $30 \%$ and started undertaking a series of far-reaching reforms with the objective of promoting new export industries. Foreign firms were encouraged to take advantage of low cost (in dollar terms) Chinese labor by investing in the

\footnotetext{
${ }^{5}$ While China arguably benefited the most from globalization, other emerging nations like, for example, Brazil and India benefited greatly as well.
} 


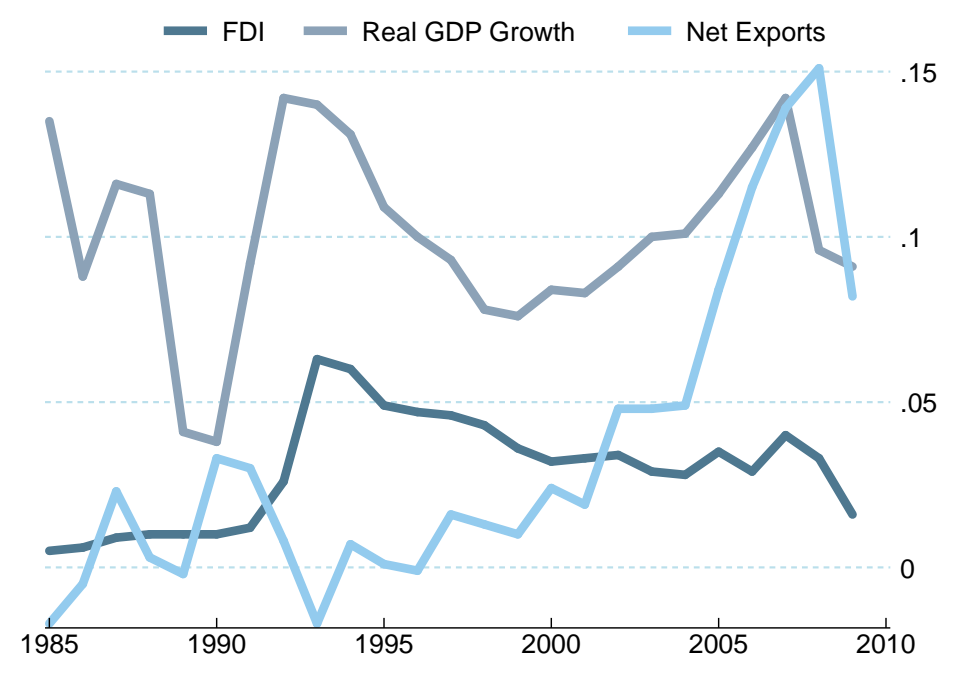

Figure 2: Foreign direct investment (FDI) as a fraction of China's GDP, China's real annual GDP growth , and gross exports as a fraction of GDP.

Source: World Bank WDI

export intensive manufacturing sectors ${ }^{6}$ The access to low cost labor ensured the competitive edge of the Chinese export sector, and virtually guaranteed foreign firms profitability as a quid pro quo for their capital accumulation and technology/skill transfer. Between 1992-1993, FDI surged from a mere $1 \%$ of GDP to more than $6 \%$ of GDP, as seen in Figure 2, and remained at more than $4 \%$ until after the onset of the crisis in 2008. The high level of FDI also set the stage for the gradual increase in net exports from around 0\% of GDP in the mid 1990s to almost $15 \%$ of GDP in 2007. The sharp appreciation of the Japanese Yen in the mid 90' 7 and the setting up of excellent infrastructure facilities by the Chinese government speeded up the moving of manufacturing operations by Japanese firms relying on US exports to China to take advantage of low cost Chinese labor. 8

China's export led growth boom has been successful in solving the problem of transferring a large segment of the rural population to coastal cities and special economic zones at the rate of almost 20 million each year. The urban population in China increased by nearly 300 million from 1990 to 2007 and in the 12 years between 1995 and 2007 the share of the urban population more doubled from less than $20 \%$ in 1995 to nearly $45 \%$ in 2007. A significant part of those who migrated to urban areas ultimately have become part of the developed world's workforce through employment

\footnotetext{
${ }^{6}$ Relatively little FDI went into manufacturing targeted at the domestic sector with the exception of a few strategic sectors, including automobiles and energy.

${ }^{7}$ The Yen appreciated by $33 \%$ between January 1994 to June 1995 and reached a high of 84 Yen/US\$ in June 1995, putting severe pressure on the profitability of Japanese manufacturing firms exporting to the US.

${ }^{8}$ Foreign firms in China remain tightly regulated and every effort is made to avoid head-on competition with domestic firms. Conditions of foreign firms may include where to locate, designation of local suppliers and operating through a joint venture. A key goal of the FDI policy throughout the 1990s remained to gain access to foreign capital as well as foreign technology, while limiting the competitive pressures on the domestic industry as pointed out in Graham \& Wada (2002).
} 
in industries exporting to the West.9 The reliance on domestic capital formation through FDI and export led growth has served to circumvent the initial technology gap and the deficiencies of domestic Chinese capital markets 10 Figure 4 shows that net exports and in particular investment became an increasingly important driver of China's GDP growth through the mid 1990s and early 2000s.

As a result of the rapid expansion of the export sector, per capita income in urban areas more than tripled from 1995 to 2007 while the disparity between urban and rural incomes widened considerably: the ratio of urban to rural per capita income increasing from 3.3 in 1995 to 4.3 in 2007. Moreover, the urban consumption rate as a percentage of disposable income dropped from $83 \%$ in 1995 to $73 \%$ in 2007 indicating that the millions of new urban Chinese workers dramatically increased their savings rate 11 There are several possible explanations for this phenomenon. It may in part be due to durable goods and housing becoming more important components of consumption for the urban worker. A second major factor is that consumer credit markets in China are not as yet as well developed as in the US, limiting the Chinese households ability to smooth consumption. Purchases of most big ticket durable items like automobiles involve little credit, and even home purchases involve about 30\% down payment. According to a study by Bingxi \& Lijuan (2009), the main lenders to consumers in China are commercial banks; and consumer loans constituted only about $12.5 \%$ of all bank loans in 2007 and $80 \%$ of those loans were for housing 12 Finally, the need to save for retirement given the one child policy and in the absence of a social security system means that even the less well off workers need to put money aside. The consequence of the frugality of the Chinese consumer can be seen from Figure 3 . The growth in Chinese savings relative to US savings has been dramatic. Chinese savings were less than a third of US savings till 2000 but grew to be $130 \%$ of US savings by 2007 .

While the US government and US households on balance benefitted from cheap credit, US workers in industries facing increased competition lose out. This view is supported by the fact that the share of wages and salaries as a percentage of US Gross Domestic Product (GDP) has dropped to $46 \%$ in 2007 from $49 \%$ in 2000 . Wages and salaries plus proprietors income dropped to $54 \%$ of GDP in 2007 from $57 \%$ of GDP in 2000. With about 117 million households in 2007, that drop in labor share of GDP translates to a drop of $\$ 3,600$ per household. However, during the same period, even though income was redistributed from citizen-workers to foreign-workers and owners of capital, the share of private consumption in the US remained at $70 \%$ of GDP. In fact, as seen from Figure 4, most of the expansion of the US economy during 2002-2007 was driven by household

\footnotetext{
${ }^{9}$ The similar transformation from a mainly rural to a urban society in the US took more than 60 years (roughly from 1860-1920)

${ }^{10}$ It has also benefitted from a period of generally rapid growth and low unemployment in the US and the West throughout the 1990s and early 2000s that limited opposition to Chinese off-shoring and Chinese imports.

${ }^{11}$ Source: Derived from China Statistical Yearbooks (1995-2008), Table 9-7/10-18.

${ }^{12}$ In contrast, credit market debt owed by the household sector in the US is comparable in size to credit market debt owed by the financial sector that includes all commercial banks and bank holding companies - the former was $\$ 13.7$ trillion and the latter was $\$ 16.5$ trillion at the end of the 2nd quarter of 2009 (Table L1, Flow of Funds Accounts of the US). See also Shimek \& Wen (2008).
} 


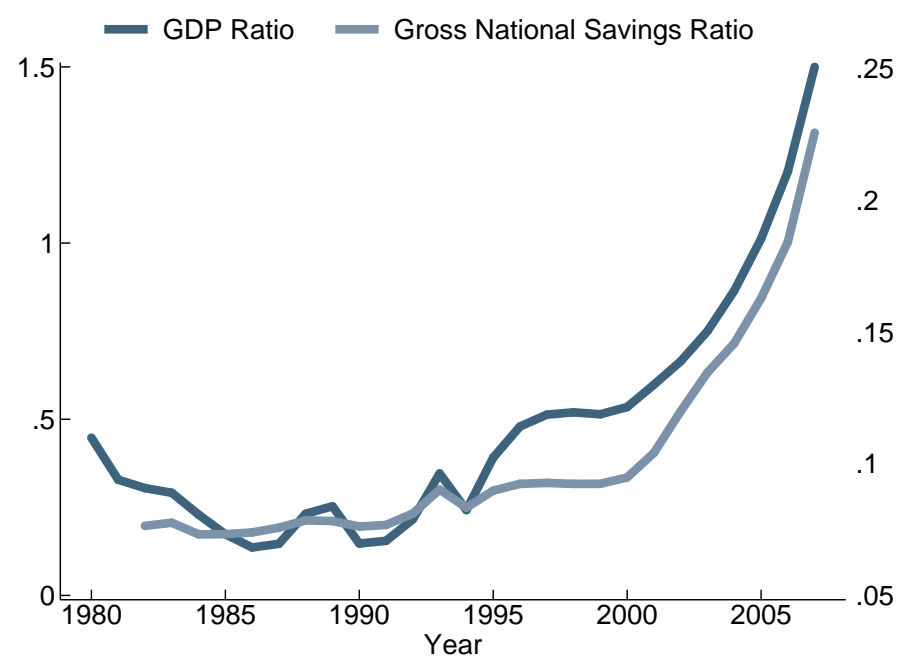

Figure 3: The ratios of China and US gross national savings (left scale) and nominal GDP (right scale). Source: Based on data from China National Bureau of Statistics and the BEA. National savings equals gross domestic investment plus the current-account balance.

consumption with very scant contributions from investment and government consumption 13 This raises the question as to why annual household consumption did not drop? We return to this important issue in Section 3 below.

\subsection{Current Account Deficits and Capital Flows into the US Housing Market}

The export led growth of the emerging economies coincided with a sharp increase in the current account deficit of the US which ballooned from $\$ 124 \mathrm{Bn}$ in 1996 ( $\$ 1,006$ per US household) to $\$ 413 \mathrm{Bn}$ in 2000 (\$3,787 per US household) and $\$ 738 \mathrm{Bn}$ in 2007 (\$6,194 per US household.) To balance this deficit on the current account, massive capital inflows took place. To understand this pattern in capital flows, one must recall that the Dollar remains the effective reserve currency of the world. Moreover most commodities are traded in Dollars. The US is therefore a natural recipient of liquidity from developing and emerging economies wishing to build up their reserves as a buffer against macroeconomic shocks, as well as those maintaining a Dollar peg. In a world where the dollar is the de facto reserve currency, a net foreign liquidity demand necessarily implies a commensurate increase in the US current account deficit. This model is sustainable as long as the demand for reserves is not too large relative to the size of the US economy. It ceases to be fiscally sustainable in the long run if the demand for reserves grows at a much faster rate than the US economy and becomes "too large" as this will tend to lead to an ever increasing debt burden as a fraction of GDP 14 This effect is illustrated in Figure 5 which shows the dollar denominated

\footnotetext{
${ }^{13}$ This is in contrast to the expansion in the 1990 s leading up to the dot com crash in which investment played a much bigger role.

${ }^{14}$ Although this effect in principle could be offset by an increase in the private savings of US households abroad, there is little sign of this on the horizon as of this writing.
} 


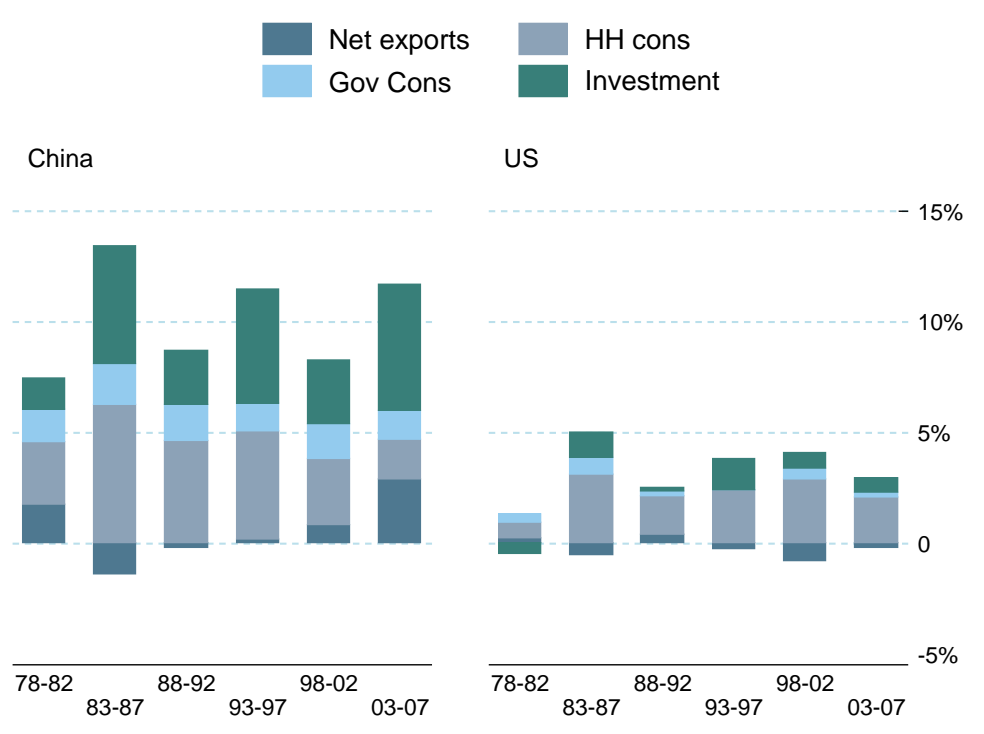

Figure 4: Average growth contributions of Net exports, Household consumption, Government consumption and Investment in China and the US between 1978 and 2007 . Source: World Development Indicators, World Bank

foreign reserve holdings held by foreign central banks as a fraction of US GDP. The foreign reserve holdings of US dollars, which had been at less than 11\% of US GDP prior to 2000, grew rapidly after 2002, in fact it almost doubled over the 5 year period from 2002 to 2007.15 Much of the demand came from the fast growing emerging economies, especially China, which, in aggregate, no longer can be considered small and whose growing demand for dollar liquidity began to have a significant impact on US financial markets.

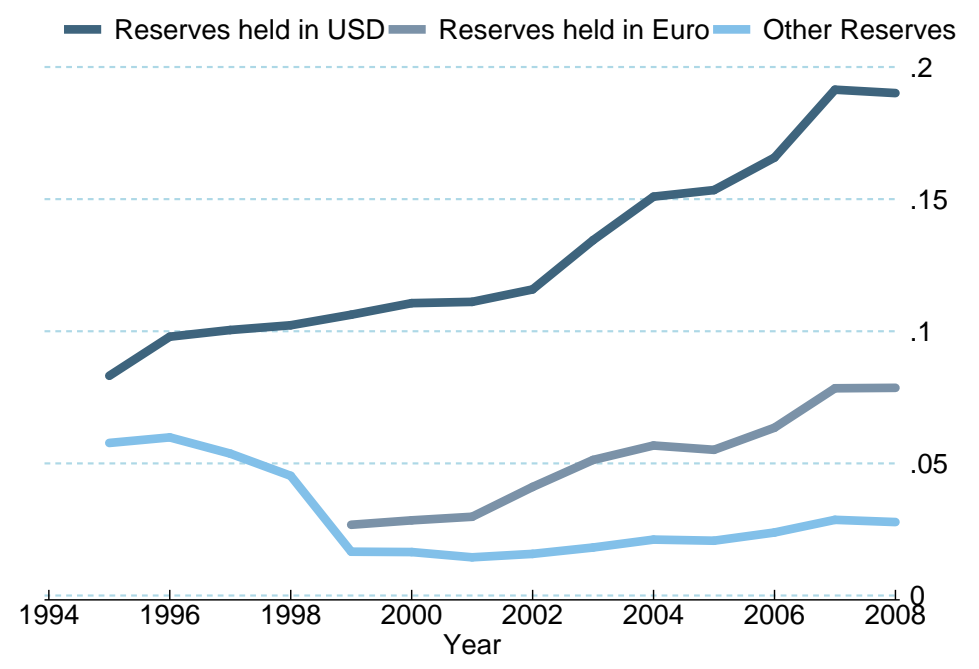

Figure 5: Foreign holdings of Dollar reserves as a fraction of US GDP. Source: IMF COFER

\footnotetext{
${ }^{15}$ This is even more remarkable as the annual US GDP growth over that period averaged almost $3 \%$.
} 
A large part of the capital flow was initially into US government debt; foreign holding of the US government debt increased from 18 percent of the total government debt of $\$ 5.66$ trillion in December 2000 to 28 percent of total government debt of $\$ 9.5$ trillion in June 2008 . These massive inflows of international reserves from emerging economies like China were largely insensitive to interest rates and put downward pressure on real interest rates across the maturity spectrum despite widening US current account deficits.

Current account deficits in and by themselves are of course not necessarily bad, provided the capital flows that occur to balance those deficits are put to productive use (e.g. infrastructure, R\&D, etc.) The flood of liquidity pouring into the US initially flowed into Treasuries and the stock market, fueling the tech bubble ${ }^{16}$ While the capital inflow did help spur innovation in the technology sector, shareholders did not necessarily benefit since they (on average) overpaid for their investments, as borne out by the crash of 2000. Much of the benefit of the technology innovation instead accrued to countries like China (and to a lesser extent, India) whose vast labor resources became much more accessible to Western companies seeking to reduce cost by outsourcing of manufacturing and services. China in particular benefited in this respect due to its vast pool of labor and the greater openness of its special economic zones developed throughout the 1990s with the initial wave of foreign investment and technology transfer, especially from Japan (with rapidly appreciating Yen) and Germany. During this period China quickly emerged as the US's fastest growing creditor, second only to Japan in size: In 1994 China held $\$ 18 \mathrm{Bn}$ in US assets (almost exclusively Treasuries) which grew to $\$ 92 \mathrm{Bn}$ in 2000 (roughly $\$ 72 \mathrm{Bn}$ Treasury debt and $\$ 20 \mathrm{Bn}$ Agency debt) and $\$ 922 \mathrm{Bn}$ in 2007 (roughly $\$ 466 \mathrm{Bn}$ in Treasuries and $\$ 376$ in agencies with the balance in corporate debt and equity), almost $25 \%$ of China's GDP.

The dramatic rise in China's trade surplus with the US should have led to a gradual appreciation of the Chinese currency relative to the US dollar which would have served to temper the rate of increase in the US trade deficit. However, the Chinese policy of maintaining the competitiveness of its export sector kept the Yuan from appreciating against the US dollar through a system of strict capital controls. As a byproduct, this policy massively increased China's dollar denominated reserves. While this strategy allowed the Chinese economy to grow by riding an export boom, it stifled the growth of domestic household consumption (at least initially). Many economists have argued that China could have made better use of its savings by investing in real capital domestically which eventually would lead to an increase in domestic consumption and imports ${ }^{17}$ In fact, as seen

\footnotetext{
${ }^{16}$ In this respect the new inflows were different in nature from the Japanese investments of the 1980's that included large investments in real assets (e.g. the Rockefeller Center) and outright acquisitions of US firms that included Universal Studios. Attempts by Dubai Ports World to take over the management of six US ports in 2006 and China National Offshore Oil Corporation's (CNOOC) bid to buy Unocal, the ninth-biggest US oil firm were stifled by political pressures.

17 "Another factor contributing to our trade imbalance with China is its exchange rate policy and its accumulation of reserves, even though trade impacts may not be the purpose of this policy. China's current account surplus, along with huge capital inflows, has created an immense accumulation of reserves $\$ 130$ billion, the second-highest level in the world. While comfortable levels of reserves are essential for every economy, especially in the context of recent financial turbulence, the levels China has reached raise questions as to whether continued reserves growth represents an efficient use of China's savings, a matter I discussed with China's leadership when I was in Beijing. China can earn higher
} 
from Figure 4, consumption played a very minor role in the rapid expansion of the Chinese economy since the late 1990s (in contrast to the US) with the main drivers of growth being investment and exports. The Chinese economy is thus extremely exposed to demand shocks from abroad, as we saw in 2008-9. However, the domestic policy objective of "maintaining social harmony and stability", meant that Chinese policy makers were keen to achieve rapid rates of GDP growth while being wary of inflation pressures and spurring too rapid consumption growth concentrated in a few urban costal areas 18 To the extent that this remains the overriding concern of Chinese policy makers, it may continue to impede the long term return to a sustainable equilibrium.

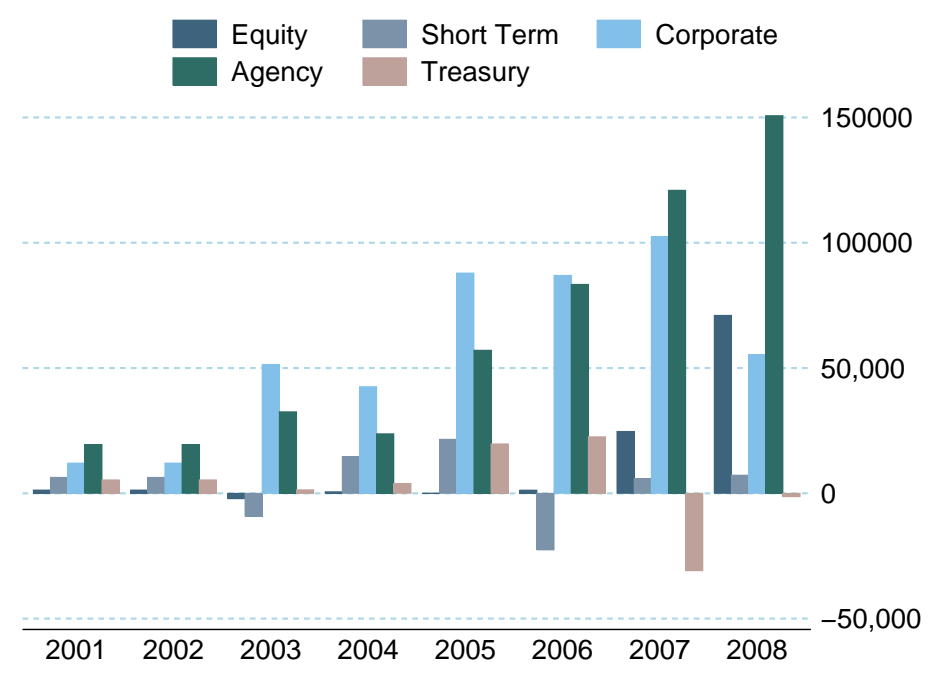

Figure 6: Change in Chinese holdings of US assets by asset class in US $\$ M$.

After the stock market crash of 2000, capital continued to flow into the US but now increasingly into safer fixed income instruments. The decreasing government financing needs and the low treasury yields made alternative government backed investments, such as GSE mortgage pools, more attractive due to the spreads these investments initially offered. Figure 6 shows the pattern of Chinese net acquisitions of US assets over the period 2001-2008. The largest increases were in corporate (including non-Agency) and Agency debt while equities did not play any significant role until 2007-8. The flow of money into securitized mortgage pools helped drive down the cost of borrowing and helped create record profits years for Fannie Mae and Freddie Mac as mortgage volumes increased 19 With the pool of conforming mortgages limited and the secondary mortgage spreads on GSE pools diminishing, investment banks set up their own pools of "private label" (non-

returns by investing in real capital than by money market investments. Such a move would not only bolster Chinese development, it would help increase Chinese imports, helping to moderate China's external imbalances.", Robert E. Rubin, speech to the Council on Foreign Relations, October 27, 1997

${ }^{18}$ The term "social harmony and stablity" is often used by Chinese politicians, e.g. President Hu Jintao speech to factory workers in Langfang, Hebei province, May 25, 2008, Xinhua news agency.

${ }^{19}$ Apart from the guarantee business, the GSEs also benefitted from the demand for agency debt which was used to finance their retained investment portfolios, the source of the bulk of their profits in the last years leading up to the crisis. 
conforming) mortgages providing investors the desired higher yields at seemingly trivial additional risk. Thus the flow of capital was ultimately funneled into the US housing market leading to the housing bubble. Figure 7 below shows the close relationship between US current account deficits and household indebtedness.

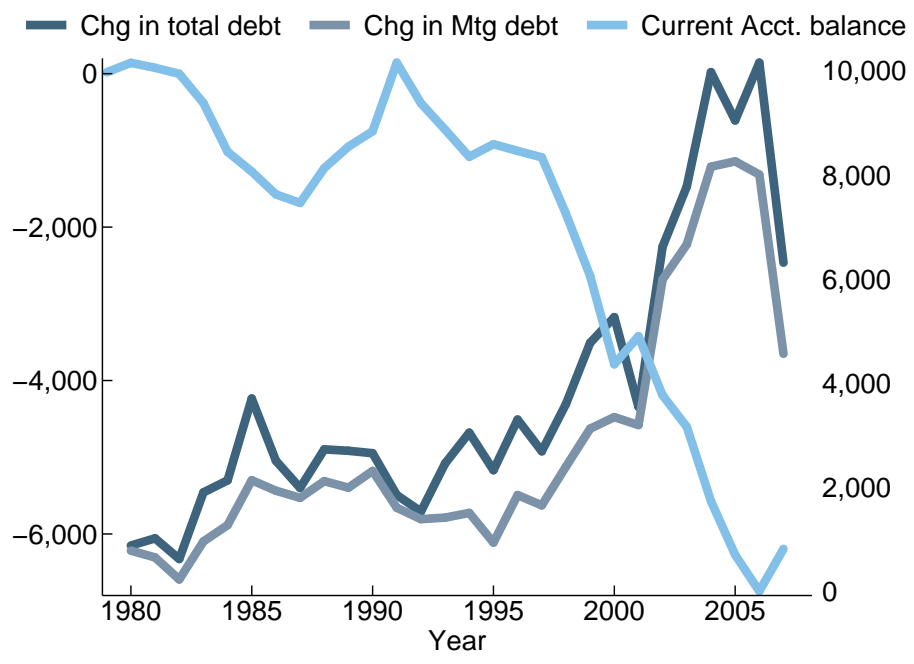

Figure 7: Current account balance and change in household indebtedness. All numbers are in US\$ per household.

Source: Treasury

To summarize, the sudden increase in labor supply from workers in developing countries because of globalization should have resulted in significant sections of the population in developed countries experiencing a decline in their living standards as more and more manufacturing and service jobs are outsourced. However, the flow of cheap liquidity from abroad during this period helped fuel the housing bubble creating the illusion of wealth among households sustaining the high level of consumption, thereby masking the real structural changes that were taking place in the world economy ${ }^{20}{ }^{21}$ We will provide support for this view in the sections that follow.

\section{US households}

It is a striking empirical fact that per capita consumption in the US grew at a steady rate of roughly $\$ 1,994$ per year over the period $1980-1999$, but jumped abruptly to approximately $\$ 2,849$ per year from 2001 through 2007 (see Figure 8). How was this remarkable increase in consumption financed? The increase happened despite the March-November 2001 recession and subsequent jobless recovery

\footnotetext{
${ }^{20}$ Households may of course simply have reacted in a (bounded) rational fashion given a belief that the housing bubble would last, as predicted by models along the lines of Ludvigson, Steindel, \& Lettau (May 2002)

${ }^{21}$ According to Krugman (2008), empirical evidence of this phenomenon might be very difficult to capture from the existing data on the trade patterns, and that may explain the why there is not much agreement on this among academics and regulators.
} 
which resulted in no significant increase in hourly earnings nor in non-farm employment rates. 22 In fact, per capita consumption in excess of wages and salary accruals and proprietors' income increased by almost $230 \%$ from approximately $\$ 2,181$ in 2000 to $\$ 7,255$ by 2007 . The stock market

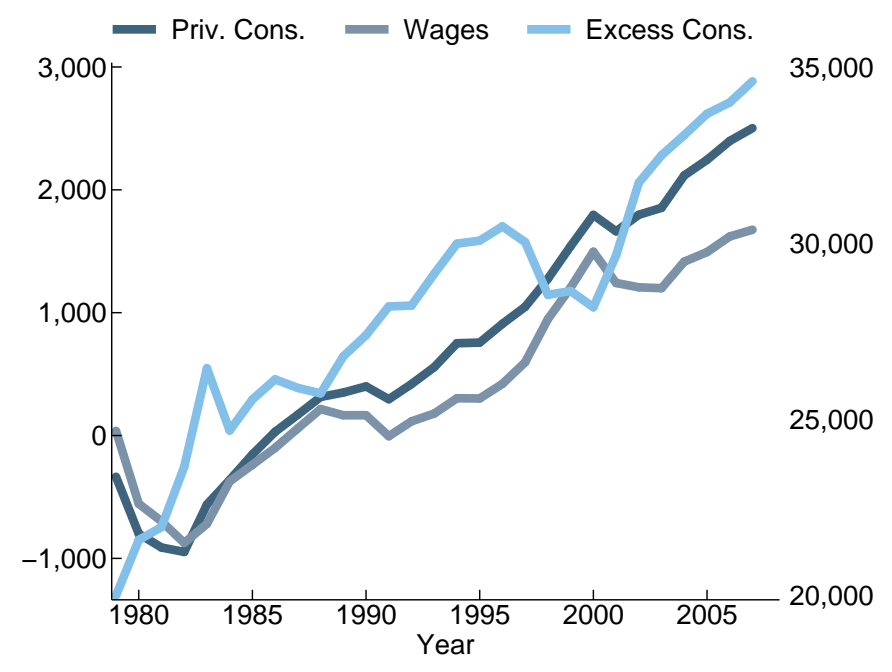

Figure 8: Private consumption and total wages incl. benefits (right axis) along with excess consumption calculated as private consumption less total wages (left axis). All numbers are in $1980 \$$ per household.

was also roughly flat between 2000 and 2007 with the S\&P500 starting at 1,499 in 2000 Q1 and ending at 1,421 in 2007Q1. The single item in the portfolio of US households which performed spectacularly well during the period was their heavily leveraged position in real estate: Home values went through an unprecedented growth spell, almost doubling in value between 2000 and the peak in early 2007.

Starting in the late 1990's the average national home value appreciation went from around 5\% per year to a peak of $15 \%$ per year in 2006 before collapsing in late 2007 (see Figure 9). Over the pre crisis period, the $\mathrm{S} \& \mathrm{P} /$ Case-Shiller home price index went from 100.77 in 2000Q1 to 186.07 in $2007 \mathrm{Q} 1$.

Despite this dramatic increase in home values, households on average did not increase their home equity much, implying that excess consumption (including consumption of larger homes) absorbed most of the windfall gains. As can be seen from Figure 10, US household residential leverage (residential mortgage debt as a fraction of residential home value) increased from about 0.42 in 2000 to about 0.52 in 2007. Consistent with this, the US National Housing Survey of owner occupied housing (c.f. Table 1 in Appendix A) shows that over the same period, the popularity of refinancing (Table 1, Panel E) and home equity lines of credit in particular (Table 1, Panel A) grew substantially until the peak of the housing bubble in late 2007.

\footnotetext{
${ }^{22}$ Between 2001 and 2003, total non farm employment declined from approximately 132 million to 130 million while the ratio of employed people to population declined from 64 percent to approximately 62 percent. At the same time, the ratio of wages and salary accruals to national income declined from 55 percent to 53.2 percent while the median
} 


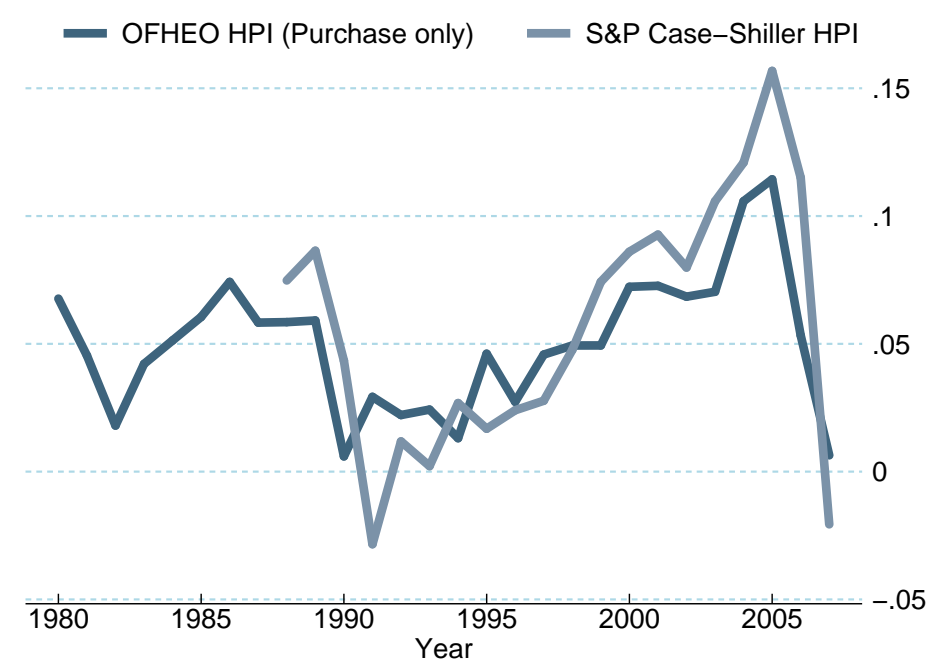

Figure 9: Home price appreciation (Q1 to Q1). Source: FHFA, Standard \& Poors

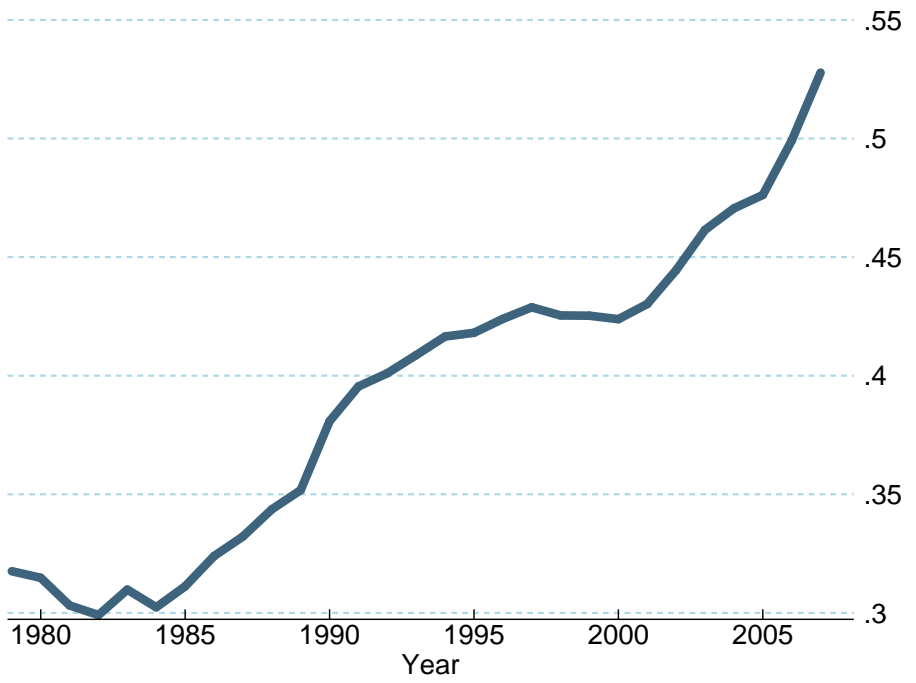

Figure 10: Average US household residential levererage computed as total residential mortgage debt divided by residential home values (primary residence only). Source: FOF, FHFA, OFHEO

The sharp increase in leverage becomes transparent when we measure leverage as the ratio of debt to wages as seen in Figure 11. The ratio of mortgage debt to wages almost doubled from about 0.6 to 1.2 , with most of the increase occurring during the $2000-2007$ period 23 .

Home prices rose sharply during 2000-2007. Whereas it took 20 years for household real estate value to increase by $\$ 72,916$ per household - from $\$ 36,437$ in 1980 to $\$ 108,633$ (2.4WS) in 2000 -

usual weekly earnings (in constant (1982) USD) remained flat at USD 325.

${ }^{23}$ Palumbo \& Parker (2009). point out that the System National Accounts for the US by the Bureau of Economic Analysis picks up the increases in the leverage of the household sector, but miss the rise in the US exposure to the housing market in the financial businesses sector. 


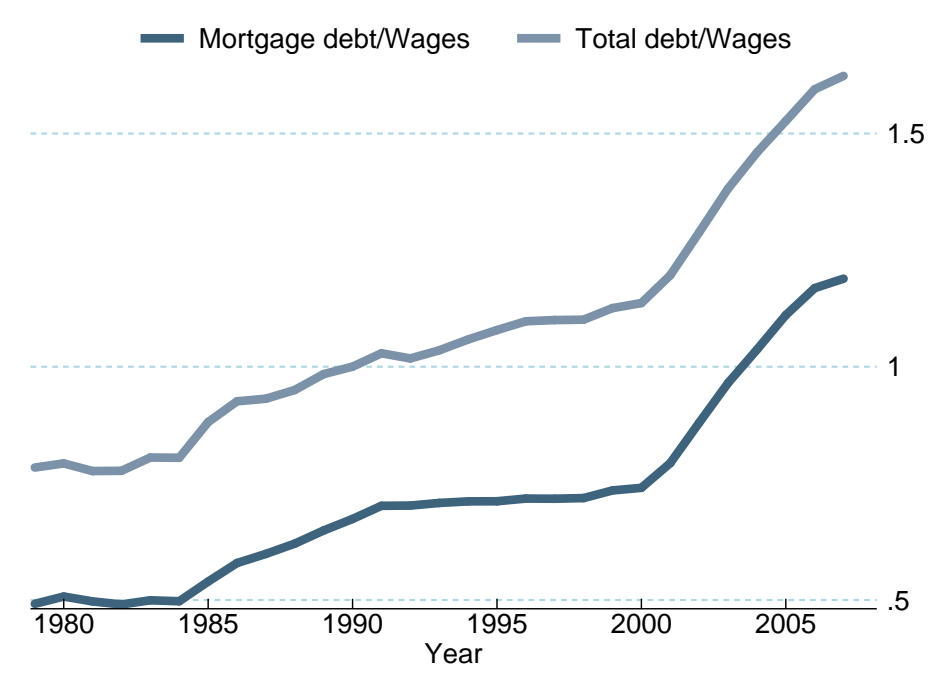

Figure 11: Average US household residential levererage computed as household debt divided by wages).

Source: FOF, BEA

it took only 7 years for it household real estate value to increase by another $\$ 63,558$ to $\$ 172,197$ by 2007. As a multiple of household wages and salaries, household real estate value increased sharply from 2.4 to 3.1 during 2000-2007, whereas it only increased from 2.1 to 2.4 during 1980-2000. While home equity rose by 52 cents for every dollar rise in home value between 1980 and 2000, home equity increased by only 29 cents for every dollar increase in home prices during the 2000-2007 period. This meant that rather than building equity, households withdrew a larger fraction of the increase in their home equity for consumption purposes, by maintaining a huge debt burden and consequently being massively exposed to the risk of falling home values, as subsequent events have borne out 2425

It is important to note, however, that the behavior of US households during 2000-2007 can be rationalized if households firmly believed that past rates of house price appreciation were

\footnotetext{
24 "The accessibility of the mortgage market to a wide variety of households has facilitated the extraction of equity in home ownership. Close to a fourth of the wealth of U.S. households, as you know, is in the form of equity in owner-occupied housing. When house prices increase, the level of this wealth-in the form of capital gains-rises, a substantial part of which is extracted as cash, mainly as a consequence of home turnover. We estimate, based on a median period of owning a home of nine years, that each home sale since 1995 has averaged roughly $\$ 35,000$ in capital gains, implying a total of $\$ 150$ billion annually for the economy as a whole. This is largely in the form of unencumbered cash, since, generally speaking, we find that the mortgage taken out by the buyer exceeds that of the remaining balance of the seller by something close to the realized capital gain. In addition, cash is extracted from unrealized capital gains through the refinancing process. While it is difficult to know precisely, at least a third to half of homeowners took some cash out when they refinanced their mortgages last year," Greenspan (1999).

${ }^{25}$ The danger of easy monetary policy leading to a boom and subsequent bust has been studied as one of the causes of the Great Depression. von Hayek (1932) and von Hayek (1934) suggest that an abrupt easing of monetary policy in the US starting in 1927 combined with the reluctance to liquidate unsound firms successfully postponed what would have been a mild recession by two years but created the preconditions for the Great Depression. In particular, Hayek argues that the policy of "easy money" leads to over-investment through "forced savings" leading to severe real distortions. In the current crisis, this raises the important question: Will the US stimulus package ultimately ease or prevent the efficient process of liquidation, and hence whether it will further steepen the eventual cost of the crisis?
} 
sustainable, and did not realize that they (or their children) would be liable for paying down the US government external debt eventually ${ }^{26}$ Understanding the fundamental forces driving housing prices is not easy and it is reasonable to assume that US households took home price increases to be permanent. Suppose households (on average) simply extrapolated prevailing economic conditions in forecasting the future, and believed that home values would continue to increase and that cheap credit would continue to be available through easy monetary policy and massive foreign capital inflows. Then the permanent income hypothesis would in fact suggest that households should increase their consumption today by borrowing extensively against their unrealized housing gains of tomorrow. In the next section we show, using a stylized rational model of household consumption portfolio choice, that US households behavior was consistent the belief that the rise in housing prices was permanent.

\subsection{A Stylized Model of Households' Consumption Choice}

We construct a stylized model of household behavior in order to better understand the response of households' consumption to a perceived increase in real estate wealth. The permanent income hypothesis states that households smooth the consumption of anticipated wealth increases over time while their consumption adjusts contemporaneously to unanticipated wealth changes. Consistent with this hypothesis, numerous studies have shown that changes in consumption are positively correlated with labor income and changes in wealth. Although one may think of housing and financial wealth as equivalent, there are a number of reasons to believe that households may respond differently to a $\$ 1$ increase in financial assets versus a $\$ 1$ increase in house prices. As Campbell and Cocco (2007) point out ${ }^{27}$, housing is a leveraged asset for the average household and a $\$ 1$ increase in housing values will act with a multiplier in relaxing a financially constrained household's borrowing constraint. Financial assets held by households, on the other hand, are typically not highly levered.28

Consider the following simple model of household behavior where households derive utility $u\left(C_{t}, H_{t}\right)$ from consumption of non-durables $C_{t}$ and housing $H_{t}$ with prices $P_{t}^{C}$ and $P_{t}^{H}$ respectively. Each period, the household is endowed with one unit of labor income worth $W_{t}$ and is subject to

\footnotetext{
${ }^{26}$ The government's debt held by citizens wash out in the aggregate, but the external debt can not grow faster than GDP forever.

${ }^{27}$ Buiter (2008) argues that there will be no pure wealth effect on consumption from a change in the fundamental value of house prices, but there will be a wealth effect due to a change in the speculative bubble component of house prices.

28 “... the equity extracted from housing does not fall unexpectedly into the sellers' laps all of a sudden. People who own a home likely have a sense of the appreciation in its value over the years. These unrealized gains may be factored into their long-term planning, and thus may influence spending on goods and services both well before and after the home is sold, rendering it difficult for models to capture this influence. For example, a middle-aged person who is sitting on a substantial unrealized gain in his or her house, but does not plan to sell for ten years, may still boost consumption today in anticipation of the realization of that gain.", Greenspan speech to the Mortgage Banker's Association, 1999.
} 
the budget constraint

$$
\begin{gathered}
S_{t+1}+P_{t+1}^{H} H_{t+1}-M_{t+1}=W_{t}-P_{t}^{C} C_{t}-T_{t}+ \\
\left(1+r_{t+1}^{S}\right) S_{t}+\left(1+r_{t+1}^{H}\right) P_{t}^{H} H_{t}-\left(1+r_{t}^{M}\right) M_{t}
\end{gathered}
$$

where $T_{t}$ are taxes, $S_{t}$ is household net dollar holdings of financial assets (other than the riskfree), $M_{t}$ is mortgage debt and $r^{S}, r^{H}, r^{M}$ are the nominal returns on financial assets, housing and mortgage debt respectively. In addition, we follow Campbell and Cocco (2007) in assuming that individual households (denoted here by subscript $i$ ) are subject to a financing constraint which must then also hold in aggregate:

$$
\begin{aligned}
M_{i t} & \leq(1-d) P_{t}^{H} H_{i t} \\
S_{t} & \geq 0
\end{aligned}
$$

where $d$ is the minimum down payment (say, 20\%).

A non-zero shadow value of the leverage constraint in (3) in the household optimization problem implies that housing wealth, labor income and financial wealth will act very differently when the leverage constraint starts to bind for more households. In particular, the results in Campbell and Cocco (2007) imply that, while we would not expect consumption to react to anticipated changes in either labor income or financial wealth, anticipated changes in housing wealth should lead to changed consumption behavior for the subset of financially constrained households. Unanticipated changes in all types of wealth, on the other hand, should have the expected immediate effect on consumption. Since we here deal only with macro-level data, we cannot check these implications directly but instead rely on a regression specification relating changes in consumption to changes in the three components of the representative household net-worth: Human capital, financial wealth, and (net) housing wealth ( $t$-stats in brackets below each point estimate) ${ }^{29}$

$$
\begin{aligned}
& \Delta\left(P_{t}^{C} C_{t}\right)=\underset{(7.74)}{683}+\underset{(7.34)}{0.712 \Delta} W_{t}+\underset{(-0.06)}{-0.001 \Delta} S_{t-1}+ \\
& \underset{(5.68)}{0.084 \Delta}\left(P_{t-1}^{H} H_{t-1}-M_{t-1}\right)+\varepsilon_{t} \\
& \operatorname{adj} \cdot R^{2}=79 \%
\end{aligned}
$$

Note that in the specification (4), we use concurrent wage income but lagged wealth changes. This can be explained by noting that households, when planning this years consumption, know their wages but do not know what return the stock and housing markets may bring 30

\footnotetext{
${ }^{29}$ Wages are a flow, but we think here of changes in labor income as a proxy for changes in the unobserved human capital.

${ }^{30}$ Note: What the optimizing agent framework buys us here (beyond the mere budget constraint) is the fact that housing wealth is different from other types of wealth due to the shadow value of the borrowing constraint and the fact that housing is both a consumption good and a store of value.
} 
Notice that our point estimate $8.4 \%$ for the wealth effect on consumption due to a change in real estate net worth is the same as the estimate reported in column I of Table 1 in Case, Quigley and Shiller (2005) obtained using data on a panel of US states observed quarterly during the 1980s and 1990s. Figure 12 shows that (4) does a good job in explaining household consumption growth, consistent with the view that US households in all likelihood were behaving rationally given a belief that the rise in home prices was permanent.

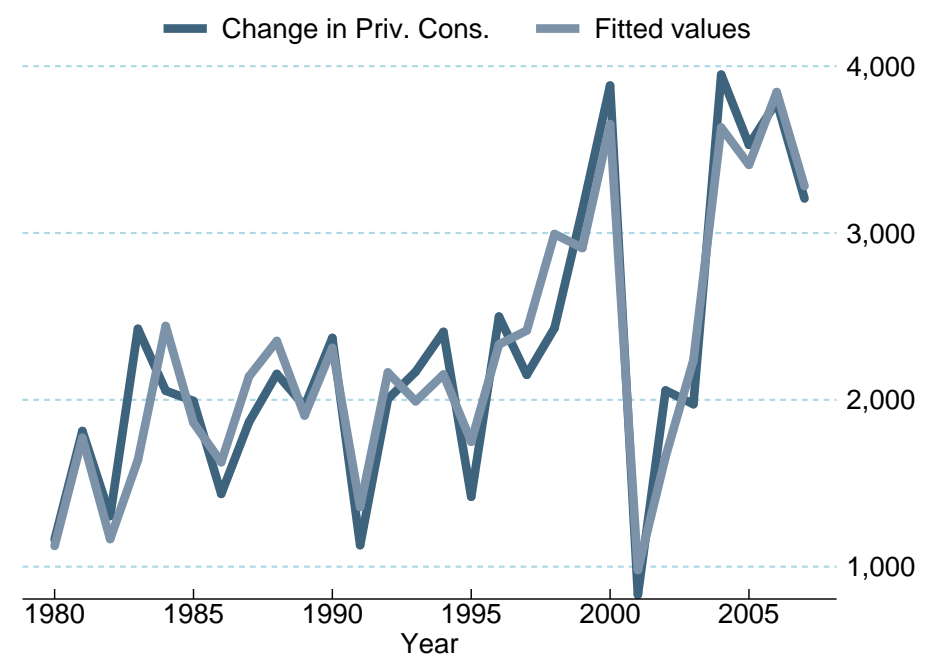

Figure 12: Year on year changes in private consumption are predicted by concurrent wages and lagged returns on housing and other financial assets. All numbers are in US\$ per household.

For every $\$ 1$ in wage increase, 71c are spent on increased consumption. The corresponding numbers for a $\$ 1$ increase in housing wealth is a $8.4 \mathrm{c}$ increase in consumption spending, while other financial asset returns have little or no impact on consumption. While our estimate of 8.4c of consumption per dollar of real estate wealth appears rather large, note that we estimate the wealth effect on consumption for other wealth to be negligible - it may be so because it is difficult to borrow against other wealth, and home mortgage interest is tax deductible 31

Having established the connection between home prices and excess consumption (leading to a current account deficit), we proceed to examine the association between the current account deficit and home prices in the next section.

\footnotetext{
${ }^{31}$ We find that the slope coefficients for the changes in domestic and foreign holdings of government debt are not significantly different from zero (results available upon request,) which is consistent with the view that investors ignore any changes in their financial liabilities due to changes in foreign or domestic holdings of government debt when making consumption decisions.
} 


\section{House Prices and the Current Account Balance}

The reaction of the real estate market (and by implication domestic consumption) to the availability of cheap and easy credit is an important channel we will consider. Denote by $B_{t}^{G}$ the level of government debt, by $T_{g t}$ the tax revenue of the government, by $T_{h t}$ the taxes paid by the households, and by $G_{t}$ government spending including transfers, then the government budget constraint is :

$$
0=B_{t}^{G}-B_{t-1}^{G}-r_{t}^{G} B_{t-1}^{G}+T_{t}-G_{t}
$$

and the current account surplus is given by

$$
C A_{t}=\underbrace{W_{t}+r_{d t}^{S} S_{t-1}-C_{t}-r_{t}^{M} M_{t-1}-T_{h t}}_{\text {household net savings, HHS }}+\underbrace{T_{g t}-G_{t}-r_{t}^{G} B_{t-1}^{G}}_{\text {Gov't savings, GS }}+C S_{t}-C I_{t}-P I_{t}
$$

where $r_{d t}^{S}$ is the dividend and interest income on financial assets (including mortgages and government bonds), $S_{t-1}$ held by households, and $r_{t}^{M}$ is the interest rate on mortgage loans, $M_{t-1}$ taken out by households, $C S_{t}$ is Corporate Savings, $C I_{t}$ is Corporate Investments, and $P I_{t}$ is Private Investments by households.

Since the trade accounts must balance, capital account flows should be equal in magnitude but opposite in sign of the flows in the current account. Therefore, from the two above equations it follows that,

$$
- \text { CapitalFlows }_{t}=C A_{t}=\left[\left(H H S_{t}-P I_{t}\right)+\left(C S_{t}-C I_{t}\right)\right]-\left(B_{t}^{G}-B_{t-1}^{G}\right) .
$$

We conjecture that to a first order, $\left(C S_{t}-C I_{t}\right)=0$, and $\left(H H S_{t}-P I_{t}\right)$ is negative and invested mostly in housing, contributing to the housing price bubble, i.e., the capital flows into the US helped build up the housing price bubble and finance the increase in government borrowing, $\left(B_{t}^{G}-B_{t-1}^{G}\right)$. In fact, the household savings rate in 2005 fell to lows not seen since the great depression (see Figure 17) and also coincided with a period of large and increasing government deficits.

Taking China as our leading example of a country with large excess savings, the story goes as follows: the Chinese channel their current account surplus into US assets, in particular government bonds and household mortgages. The supply of Treasury securities, however, is limited, so much of the excess liquidity is absorbed in the mortgage market, leading to a positive feedback effect illustrated by the following stylized example:

Suppose households increase consumption by $\$ 1$ today of which roughly $17 \mathrm{c}$ are spent on imports from e.g. China. Due to the high savings rate abroad, suppose 2c are channeled back into "safe" US denominated fixed income assets held by central banks and foreign households. If the supply of US government bonds is limited, treasury yields will start to drop to the point where foreigners in search of higher yields will find household mortgage debt attractive. That will increase the 
supply of mortgage debt - and in equilibrium result in an increase in the outstanding pool of home mortgages, in part due to reduction in mortgage interest rates and in part due to willingness to relax mortgage lending standards. This in turn has a direct wealth effect (lower payments) and an indirect wealth effect (increased demand for housing leads to house price inflation) which in turn results in higher consumption tomorrow.

As we will see later, a $\$ 1$ increase in inflows due to current account deficit is associated with almost a $\$ 2$ increase in home values. The wealth effect (8.4\% of increase in home value) will result in an increase in consumption of $16.8 \mathfrak{c}$ and a consequent increase in imports of about $3 \mathfrak{c}$, i.e., the $4 \mathbb{c}$ flow back into the US will result in a $0.67 \mathrm{C}$ increase in consumption, and a $0.11 \mathrm{c}$ increase in imports. For the magnitude of the feedback effect to be much larger and significant, the share of imports in the increased consumption has to be much higher due to the change in the nature of the basket of goods consumed, and a majority of the households must be liquidity constrained, resulting in US households substantially leveraging their housing wealth for consumption purposes through home equity lines of credit.

To test this feedback from current account deficits to mortgage markets, we consider three regression equations estimated using annual data for the period 1980 - 2007.

First we examine the impact of the current account balance $\left(C A_{t-1}\right)$ on the growth (change) on the pool of Agency and private label residential mortgage pools $\left(\Delta M P_{t}\right)$. We expect to see the growth in outstanding mortgage pool increase in response to an increase in the current account deficit (i.e., decrease in current account balance) with a one year lag to allow for transactions to take place. We also add the contemporaneous change in treasury issuance since it is exogenous (determined by government funding needs) and, according to our story, may crowd out demand for mortgage backed securities.

$$
\begin{array}{r}
\Delta M P_{t}=\underset{(4.90)}{906.79-1.11} C A_{t-1}+\underset{(-12.71)}{0.06} \Delta B_{t}^{G}+\varepsilon_{t} \\
\text { adj. } R^{2} \approx 91 \%
\end{array}
$$

We find that almost the entire dollar increase in current account balance goes towards increasing the pool of outstanding Agency and private label mortgages. As can be seen from the Figure(13), the regression captures some of the turning points in the growth rate in the mortgage pool.

Second, we examine the change in residential home values $\left(\Delta P_{t}^{H} H_{t}\right)$ in response to a change in the pool of outstanding Agency and private label mortgages $\left(\Delta M P_{t}\right)$ after controlling for the mortgage interest rate $\left(r_{t}^{M}\right)$. The t-statistics of the estimated parameters using Newy-West standard errors with 6 lags are also provided.

$$
\Delta\left(P_{t}^{H} H_{t}\right)=\underset{(-1.17)}{-1684}+\underset{(2.09)}{227} r_{t}^{M}+\underset{(11.34)}{1.49} \Delta M P_{t}+\varepsilon_{t} \quad \text { adj. } R^{2} \approx 77 \%
$$



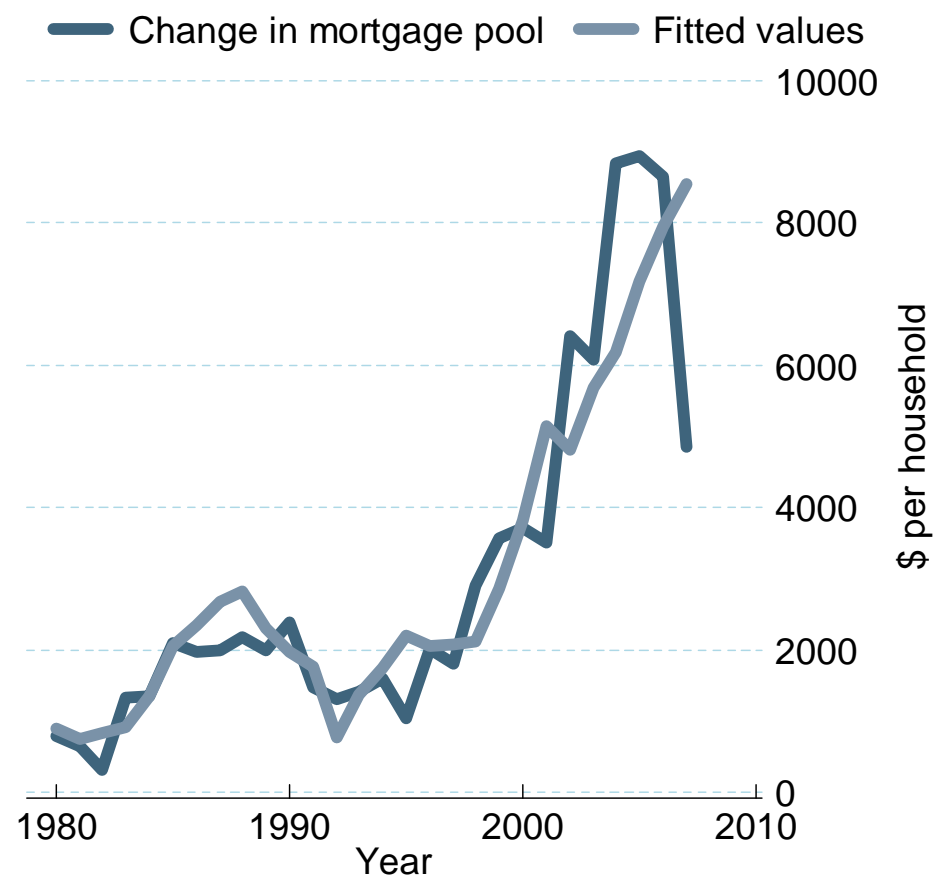

Figure 13: Change in Outstanding Mortgage Pool per HH vs CAB per HH

Again, as can be seen from the Figure(14), the regression captures some of the turning points in the change in residential real estate values.

To summarize, the evidence is consistent with the view that the capital account flows that offset the current account deficits were channeled into residential housing and that contributed to the housing price bubble 32 We will return to this point when we discuss the international evidence below.

These findings support the feedback effect: US households consumed more than than their income because they felt wealthier due to home price appreciation. Excess consumption led to increase in current account deficit. For accounts to balance, there was a corresponding inflow of foreign capital that was channeled into home mortgages leading to a rise in home prices. That fueled continued excess consumption and the cycle continued for a while. Figure 15 illustrates that the size of the current account balance deficit was roughly of the same order of magnitude as the mortgage origination in the US. We now examine the role of financial engineering in channeling foreign funds flowing into the US into housing.

\footnotetext{
${ }^{32}$ This is not inconsistent with Favilukis, Ludvigson \& Nieuwerburgh (2010) who show that a two sector general equilibrium model with housing, when calibrated to match the increased foreign ownerhsip of US Treasury debt due to financial market liberalization, can generate large increases in housing prices as observed during the 2000-2007 period in the US.
} 


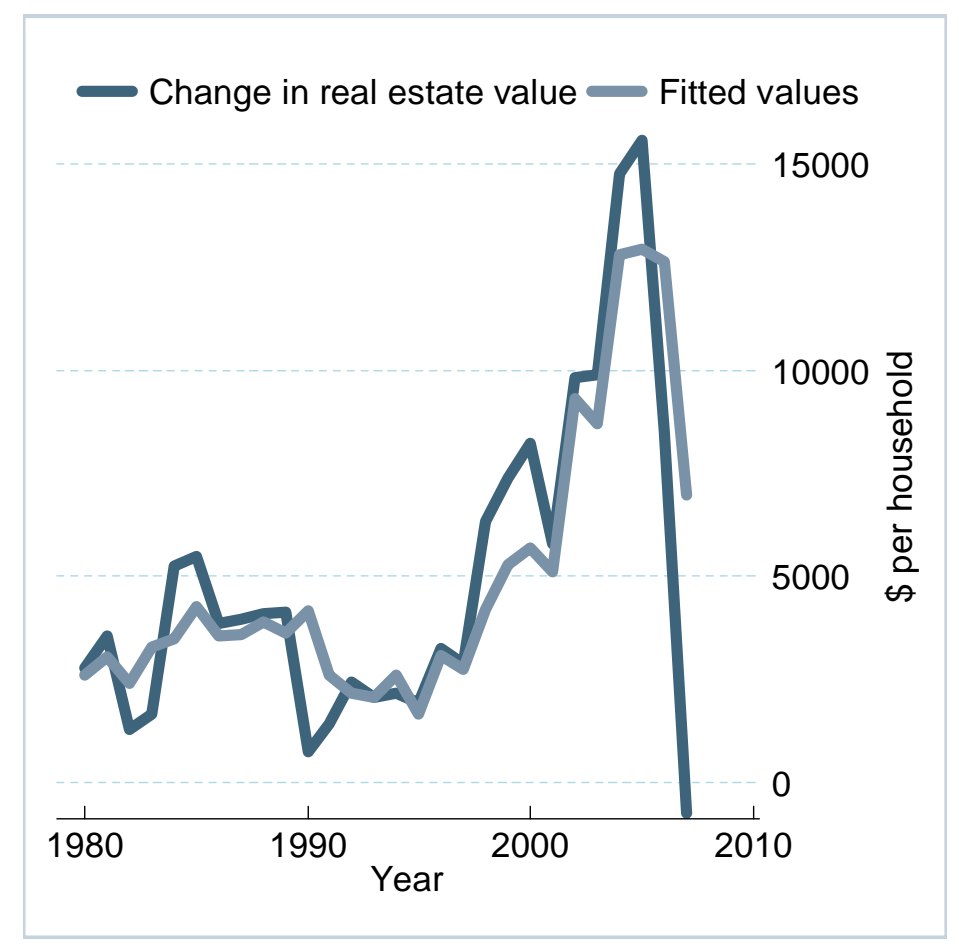

Figure 14: Change in residential real estate value vs change in outstanding mortgage pool and mortgage interest rate

\subsection{The Role of Financial Engineering}

Wall Street and financial engineering played an important role in facilitating what was already a crisis in the making, as described in Sections 2 and 3. With US current account deficits reaching record levels, foreign savings were flowing into the US and especially fixed income markets lowering yields on Treasuries and sending investors looking for higher yielding low risk alternatives such as mortgage backed securities (MBS) ${ }^{33}$ Financial innovation and regulatory arbitrage spurred by the excess demand for low risk investments created the securitized banking system (a.k.a. shadow banking system) in which intermediaries originated/acquired mortgages for the explicit purpose of creating "diversified" pools of assets that could be financed by short term debt and sold on to investors. 34 A second consequence was the increased rehypothecation of assets in high demand that was facilitated by very low margin requirements given the low risk of the underlying assets. This set the stage for a leverage cycle as discussed by Geanakoplos (2009). While the "rehypothecation" and staggering amounts of leverage available in repo markets arguably played an important role in the propagation and amplification of the housing bubble, it itself was only made possible by the ample supply of "real" money that both bought the mortgages and supplied the leverage used by the intermediaries in creating the pools.

The diversification logic of the credit rating agencies (largely based on the fact that the US had

\footnotetext{
${ }^{33}$ See Boyd, Jagannathan and Kwak (2009) for a discussion.

${ }^{34}$ See Pozsar, Adrian, Ashcraft \& Boesky (2010) for an excellent overview.
} 


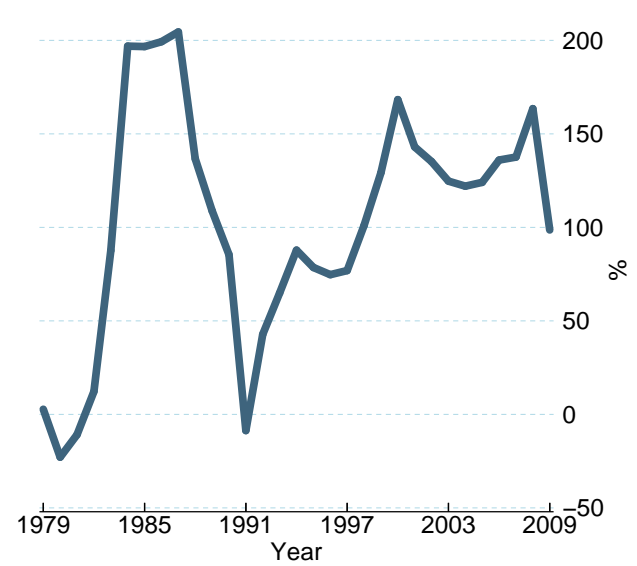

(a)

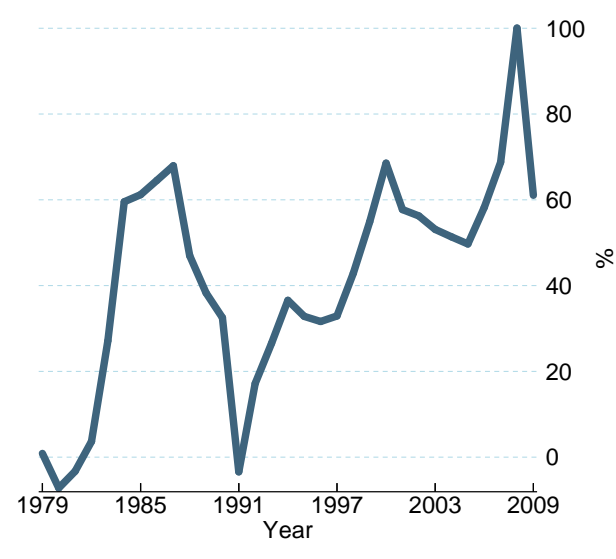

(b)

Figure 15: Size of current account deficit relative to housing market. Panel (a): Ratio of current account to estimate of mortgage origination associated with home sales (estimate based on total number of home sales and average mortgage debt per homeowner). Panel (b): Ratio of current account balance to total value of existing and new home sales.

Source: FHFA

not seen a nationwide house price collapse since the Great Depression), allowed for the creation of seemingly risk-free assets by tranching pools of risky individual mortgages, the so called "private label" Asset Backed Securities 35. While the private label ABS market had steadily increased in market share throughout the 1990s and early 2000s, it really took off at the end of the 2001-03 recession reaching a market share of around $50 \%$ by the end of 2006, as seen in Figure 16 . As production of AAA rated securities was ramped up, there was a lack of good quality mortgages to securitize, leading to the erosion of underwriting standards, as discussed by Foote, Gerardi, Goette \& Willen (2008). Figure 16 the rapid increase in risky sub-prime, alt-A and home equity mortgages coinciding with the explosion in private label ABS.

With rising housing prices and low rates on alternative investments, investors were tempted to reach for higher subprime yields, ignoring the potential for hitherto unseen levels of delinquencies down the road. The collective failure to internalize low probability aggregate risk distorted incentives and created the fragility as agued by Gennaioli, Shleifer \& Vishny (2010).

To summarize, financial engineering greatly expanded the capacity of the US housing market to absorb the money that was flowing into the US at increasing rates, thereby allowing households to achieve record high levels of leverage, as seen in Figure 11 and 10. Although real estate values went up by $\$ 10,037$ per household from $2004-7$, the average home equity actually fell by $\$ 10,566$ over the same period, indicating that households, on average, were cashing out even faster than

\footnotetext{
${ }^{35}$ Prior to 1990 , the Agency mortgage pools, consisting of conforming (e.g. 30 year fixed rate, $\leq \$ 417 \mathrm{~K}, \geq 80 \%$ Loan-to-Value) first lien mortgages, were pretty much the only game in town when it came to mortgage backed securities, with private label issues playing only a relatively minor role (see Figure 16). During the late 1990's a flurry of innovation took place in the mortgage industry, with new mortgage types being created which allowed homeowners to take bets on mortgage rates and enabled otherwise unqualified buyers to qualify for mortgages by deferring payments. These non-conforming mortgages were securitized through so-called "private label" Asset Backed Securities (ABS) sponsored by Wall Street.
} 


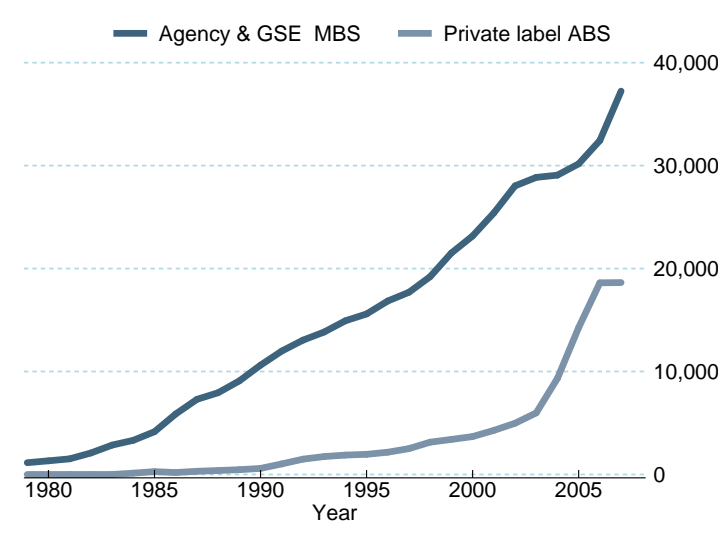

(a)

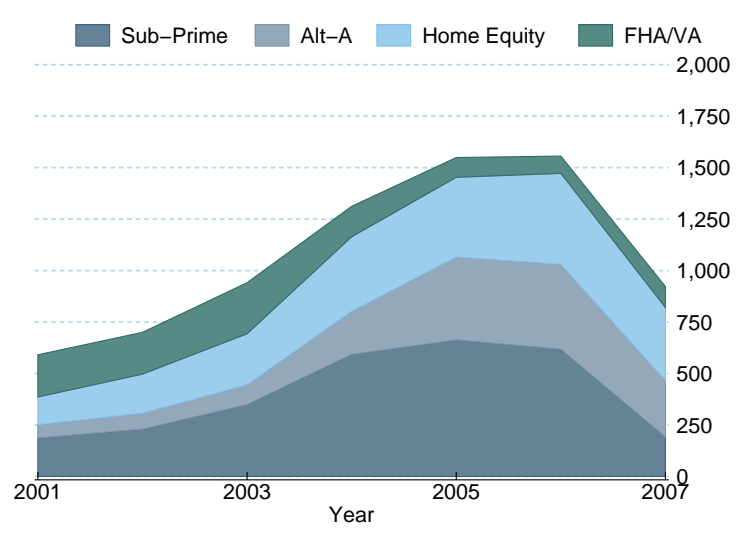

(b)

Figure 16: Panel a: Outstanding mortgage backed securities by issuer in US\$ per household. Panel b: Origination of non-prime mortgages in US\$M.

Source: FHFA \& Federal Reserve

house prices went up. The explosion in private label ABS also coincided with an equally remarkable deterioration in the current account, as seen in Figure 7. At the end of 2006, subprime and alt-A loans accounted for roughly $72 \%$ of ARM debt outstanding - that is roughly $\$ 2.5$ trillion in debt, or $25 \%$ of the total mortgage debt outstanding. This represents about 9.6 million loans, or roughly $19 \%$ of the total number of mortgage loans outstanding. The money flowing into the housing market led to the housing price bubble: The S\&P Case - Shiller home price index increased from 100.77 in 2000 Q1 to 186.07 in 2007 Q1, i.e., an increase of $86 \%$.

\subsection{The Role of the Government}

Certain actions taken by the US government and its agencies during the 2001-2007 period have been suggested as contributing factors in the buildup to the financial crisis.

While fiscal policy may have played some role in laying the ground work for the financial crisis, it was less important than the behavior of the private sector and households. During mid 80s, government deficits were around 4.5\%, larger than the Balance of Payment deficits which were around $3.25 \%$. Since the capital flows into the country that were needed to offset the current account deficits were smaller than the government deficits, part of the government deficits were offset by net domestic private sector savings, i.e., the private sector accounted for a net surplus of capital flows. In fact, even personal savings as a percentage of personal income started falling only after 1984 (see Figure 17). This had changed dramatically starting in the late 90's. By 2006, the federal deficit was around $2.5 \%$ and dwarfed by the current account deficit of around $6 \%$, the result of a decade of net capital inflows. In other words, while the government deficit is clearly important, it was not the main driver of capital inflows during the buildup to the recent crisis 36

\footnotetext{
${ }^{36}$ Ever since the first income tax was introduced in the US in 1894, interest expenses have been deductible with the original logic being that most interest expenses were associated with the running of farms and businesses. The deduction effectively treats mortgage interest as a business expense thereby allowing homeowners to deduct it from taxable income. However, whereas a business must pay tax on the net income with which the interest expense was incurred, homeowners do not pay tax on the imputed rental value of their own home. The mortgage interest deduction
} 


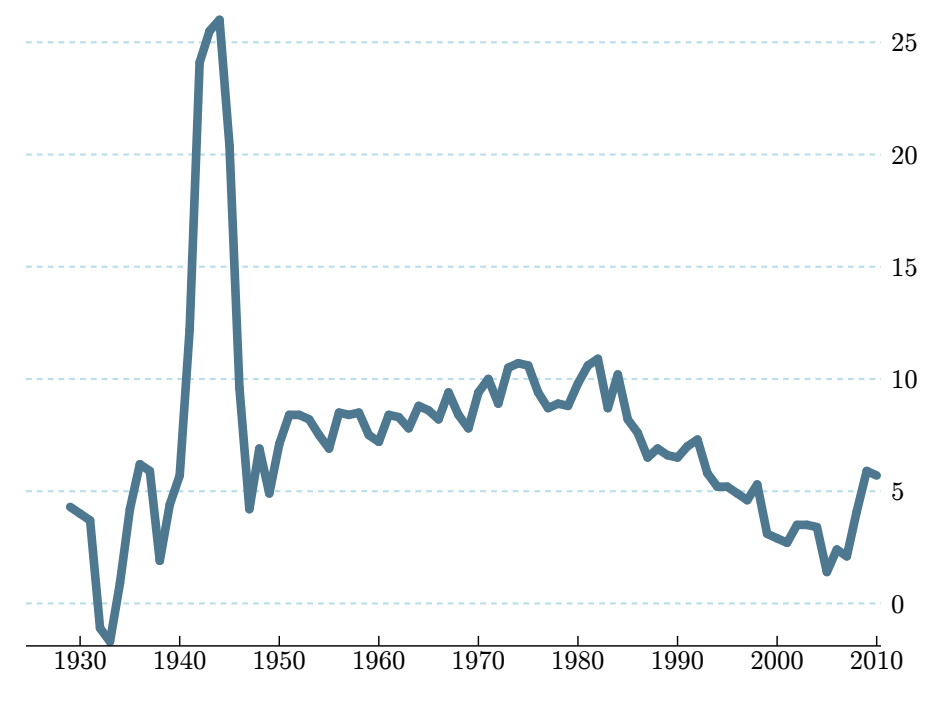

Figure 17: The personal savings rate of US households. Source: BEA

The stance of monetary policy during the post recession 2002-2005 period was arguably very accommodative with the real short rate in negative territory during much of the period. Combined with a steep slope of the yield curve, it no doubt provided an incentive for homeowners to shift into riskier ARMs and for investors to finance short and invest long. While the low level of the policy rate may have played a role in the channeling funds into home mortgages, it can hardly be blamed for the poor quality of the subprime mortgages originated with much of the expansion coming from the subprime and Alt-A segments. Moreover, it is difficult to make the direct link between the level of the fed funds rate and house prices given that the rate of house price increases accelerated sharply in 2005 and 2006 long after the fed had started tightening substantially.

Arguably the most direct way in which government policies helped spur the housing bubble was through the affordable housing mission given to the government sponsored enterprises (GSEs) Fannie Mae and Freddie Mac by Congress in 1992 in order to expand housing opportunities for low- and moderate-income families. In a nutshell, the basic business model of these GSEs consisted of two lines of business. The first, was the securitization and guaranteeing of conforming prime mortgages which required a relatively low level of capital reserves ( $2.5 \%$ was mandated) given the high quality of collateral (the federal government providing the ultimate tail risk insurance). The second line of business was the retained portfolio of investments in MBS which was allowed under the charter as long as the tranches purchased satisfied the $80 \%$ LTV requirement. The GSEs could not guarantee subprime mortgages directly in order to fulfill their affordable housing mandate. Instead they were allowed to purchase ostensibly safe tranches of private label MBS securities backed by subprime mortgages and count these investments toward their obligations to lend to lower-income home buyers. In addition both Fannie Mae and Freddie Mac bought huge amounts of Alt-A and

under US tax law therefore represents a subsidy to the housing market, but cannot hardly be blamed for a bubble occurring a century later. 
option ARM mortgages (although these did not count toward their HUD requirements) at very attractive spreads to their near treasury cost of funding. In fact, the majority of the profits made by the GSEs in the years leading up to the crisis came from the retained portfolio (arbitraging the implicit tax-payer guarantee of agency debt) rather than the core guarantee business. The ability to lever up 40 times, meant that the GSEs' retained portfolios (much of it subprime) quickly grew to gigantic proportions and on the eve of the crisis in 2007 the GSEs, with more than a trillion dollars in their retained portfolios, were the single largest subprime investors ${ }^{37}$

\subsection{Why Did the Bubble Burst?}

The remarkable economic growth in emerging nations was associated with a rapid increase in prices of intermediate production goods and especially commodities, with the Goldman Sachs Commodities index more than quadrupling between 2002 and the peak in early 2008. While the wages of the median US worker grew modestly, and in line with the core CPI, over the same period, the volatile food and energy components of the CPI started growing at an accelerated rate in late 2003 through early 2008 (see Figure(18)). This caused trouble for many subprime home owners with high back-end debt-to-income ratios for whom food and energy take up a significant share of disposable income. By mid 2007, many subprime households were effectively left with the choice between filling their trucks and fridges or paying their mortgages which lead to a steep rise in 90+ day delinquency rates for the 2005-2007 vintages which arguably had the worst underwriting standards. Interestingly many defaults started occurring within 12-18 months of origination, well before the reset date of subprime ARMs, indicating that the cause in many cases was related to a cash flow problem rather than just the inability to refinance after the initial teaser rate reset (see Figure (19) 38

As subprime households started to default on their loans, downward pressure on house prices resulted due to foreclosures. Spreads on MBS tranches started blowing out putting subprime originators in trouble, leading to the Bear Stearns hedge fund collapse in 2007, and forcing banks to bring more of the MBS exposure onto their balance sheets. The resulting funding problems at subprime and Alt-A lenders led to an increase in the number of disqualified borrowers due to tightened credit standards and "disintermediation" (see Figure 20) . Repricing of risk in the market in combination with the declining value of their collateral also dried up the availability of new teaser rate loans to home owners with existing ARMs, leading to further self-reinforcing waves of loan defaults 39

Sophisticated investors who saw signs of events that could trigger the collapse of the housing

\footnotetext{
${ }^{37}$ In the aftermath of the crisis, a large number of articles have been written on the the role of GSEs, see e.g. Wallison \& Calomiris (2009) for an early discussion.

${ }^{38}$ See Haughwout et al (2008) for a detailed discussion of the early delinquency phenomenon which is otherwise hard to reconcile with other macro economic shocks or strategic defaults by households.

${ }^{39}$ Foote, Gerardi, Goette \& Willen (2008) found that over $60 \%$ of subprime originations prior to 2004 were refinanced within 2 years. In their sample, the initial two-year rate was $7.3 \%$ in 2004 , rising to $8.5 \%$ in 2006 while the corresponding prime ARM rates were $3.9 \%$ in 2004, rising to $5.5 \%$ in 2006 . By comparison, the corresponding fully indexed ARM rates were $11.5 \%$ and $9.1 \%$.
} 


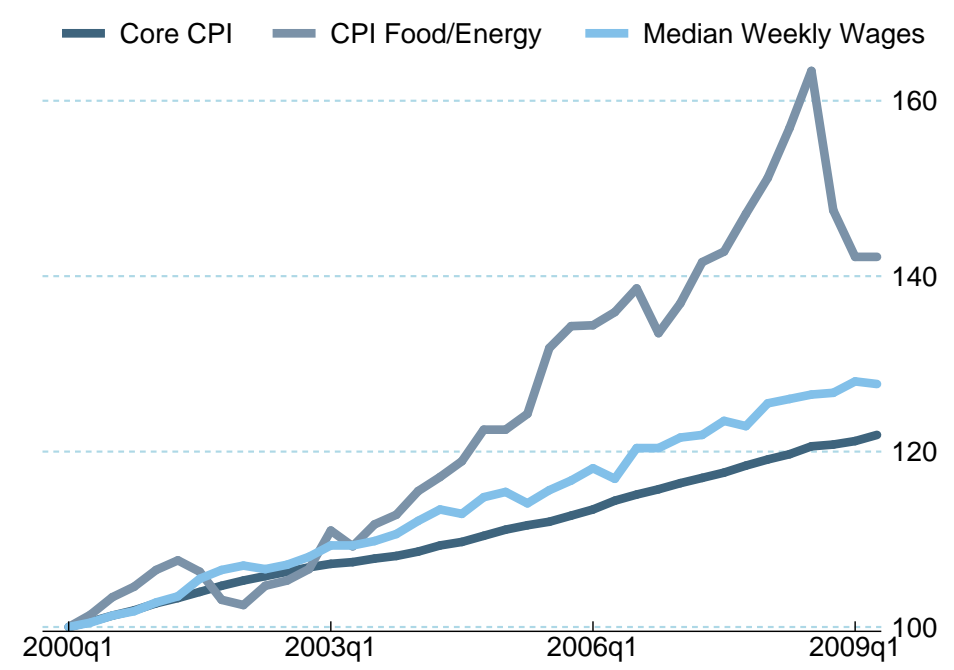

Figure 18: Core Consumer Price Index (excl. food \& energy), the food \& energy component of the CPI, and the median hourly wages of all employed older than 25 years. All numbers are quarterly and indexed to 2000 levels.

Source: BEA \& BLS

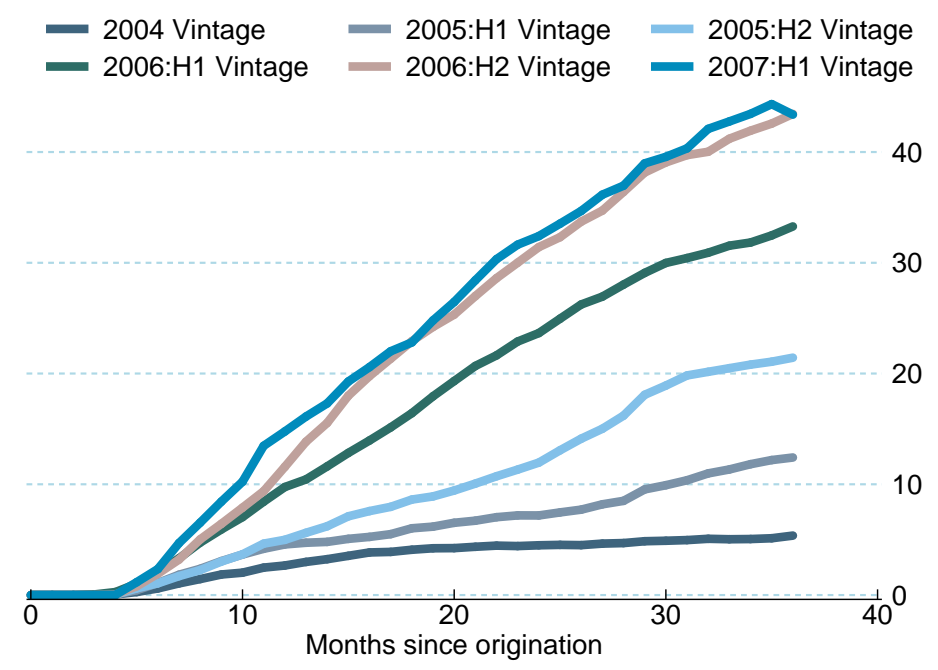

Figure 19: Cumulative serious delinquency percentage rates (90 days+) for subprime vintages as a function of months since origination.

Source: LoanPerformance

bubble started taking a short position on US housing. Wall Street created financial instruments to meet the demand for shorting the US housing market. In early 2006, the first subprime mortgage backed credit derivative indices were launched (e.g. the ABX.HE index) in order to allow investors to take bets on the subprime market without holding the underlying asset backed securities. According to subsequent reporting in the press, investment banks and large hedge funds started making large leveraged bets against subprime using these newfangled instruments by late 2007. Thus financial engineering, which had helped bring about the housing bubble in the first 
place, also played an instrumental role in the bursting of the bubble 40

The sub-prime ARM debacle was eerily reminiscent of the experience with the short term balloon mortgages that were the norm prior to the Great Depression. On such balloon mortgages, the principal was at most partially amortized at maturity, leaving the homeowner with the challenge of refinancing the balance at maturity. During the Great Depression, this system of home financing resulted in a lengthy period of foreclosures and defaults as homeowners could not roll over their mortgages. As a direct consequence of this experience, the Federal Housing Administration (FHA) popularized the 30 year fixed rate mortgage in the 1930s as a standardized long-term, selfamortizing, home loan that allowed homebuyers to lock in fixed, affordable monthly payments over the entire life of the loan. It allowed generations of Americans to accumulate wealth for retirement by building equity in their homes. This was yet another lesson from the Great Depression that was forgotten by the financial community by the early 2000 s.

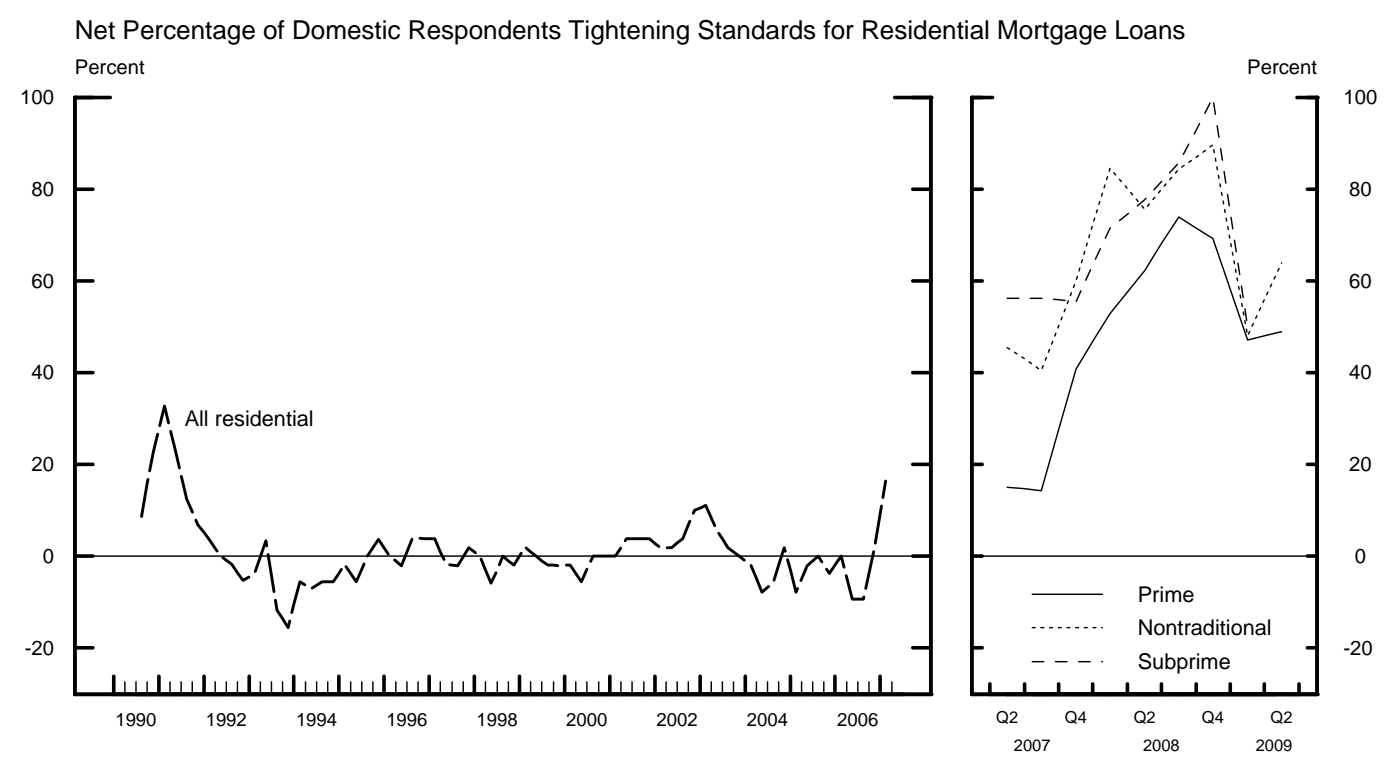

Figure 20: Percentage of loan officers at major US credit institutions reporting tightening of credit standards over prior year for residential mortgage loans.

Source: Federal Reserve Survey of Loan Officers

\section{$5 \quad$ Why Housing Bubbles are Different}

In this section we elucidate why even a relatively modest housing bubble may have more severe real effects than other asset price bubbles, e.g. a stock market bubble.

\subsection{Money Channeled into Housing has a Bigger Price Effect}

To understand why money channeled into housing can have a bigger price effect, consider the following hypothetical economy with 10 households. Each household has $\$ 100$ in housing wealth

\footnotetext{
40 "Banks Bundled Bad Debt, Bet Against It and Won", New York Times December 14, 2009
} 
and $\$ 100$ in stocks. Suppose there is a sudden helicopter drop of $\$ 10$ per household, that each household has to use in bidding up the prices of stocks or housing.

First, suppose households decide to use the money to bid up the price of stocks. The total value of stocks before the helicopter drop of money was $\$ 1,000$. The total value of stocks will go up by $\$ 100$, the total amount of money dropped, i.e., an increase in price of $10 \%$. Whether everyone invests their $\$ 10$ directly in stocks or nine of the households lend their money drop to the tenth household which in turn invests the $\$ 100$ ( $\$ 90$ borrowed plus $\$ 10$ of its own) in stocks does not matter. The price effect on stocks will be the same. There is no leverage effect in the aggregate, since stocks are homogenous.

Next, suppose households decide to invest the money to bid up the price of housing. When there is no leverage allowed, and each household bids up the price of its own house, the price rise will be $\$ 10 / \$ 100=10 \%$.

Suppose leverage is allowed. Nine of the households give their money to a bank. The bank lends the $\$ 90$ to one household. That household uses that to bid up the price of its house. The price rise will be $\$ 100 / \$ 100=100 \%$. Other households will also think their house value has gone up by $100 \%$, since assessors use comparables for home valuation 41 Hence there is leverage even in the aggregate in housing and there is a money multiplier effect on housing prices. The same amount of money flowing into housing is likely to cause a bigger price rise. This is consistent with Piazzesi \& Schneider (2009) who show that a small number of optimists can drive up the average transaction price of houses without a large increase in trading volume or market share.

Like all bubbles the housing price bubble also collapsed eventually. The wealth effect that kept consumption up vanished. The financial intermediaries that channel money into housing were also highly levered, worsening the situation when the bubble burst. The recession followed.

\subsection{A Housing Bubble is Different from a Stock Market Bubble}

It is interesting to contrast this experience with the even more dramatic (in percentage terms) stock market collapse in 2000. While the stock market downturn led to the shallow recession of 2001, the collapse of the housing bubble has led to a much more severe recession now ${ }^{42}$ While the real effects of the recession following the stock market collapse were largely ameliorated by the highly accommodative monetary policy which saw the federal funds rate lowered from $5.31 \%$ in March 2001 to $2.09 \%$ in November 2001, it can not explain the severity of the recession we are facing now.

A crash in the value of home values has a far more severe impact on the economy than a

\footnotetext{
${ }^{41}$ Unlike stocks, houses are illiquid with few transactions relative to the number of homes in the economy. As Piazessi and Schneider (2009) observe, less than $6 \%$ of owner occupied houses are traded during a typical year whereas the annual trading volume for stocks in the NYSE is about $120 \%$. In view of that the common practice is to value houses by examining the price at which a similar comparable house transacted recently.

${ }^{42}$ That the bursting of real estate bubble, unlike the bursting of the stock market bubble, can have disastrous consequences is well recognized by economists. For example, Franklin Allen, in his keynote address at the 8th Asia Pacific Finance Conference held in Bangkok (July 22-25, 2001), cautioned that the bursting of the real estate bubble might lead to a long recession in the US just like that in Japan.
} 
corresponding decline in the value of stocks for the following reasons.

Residential real estate constitutes a substantial part of household wealth for most households. For the middle three wealth class quintiles of the population, the principal residence constituted $66.1 \%$ of the value of the total household assets, whereas corporate stocks and financial securities constituted only $7.9 \%$ (cf. Table 7, Wolff (June 2007)). In 2004, 48.6\% of all families held stocks, with a median value $\$ 24,300$. In contrast, $67.7 \%$ of all families owned their primary residence, with a median value of $\$ 131,000.43$

Investment in housing typically involves leverage, whereas there is relatively little leverage in stock investments. For example, mortgage debt was about $47.4 \%$ of residential real estate value in 2004 whereas other debt was only $6.8 \%$ of the value of the other assets of households. Averages understate the leverage available for investing in residential homes. For example, $51 \%$ of all loans that originated in 2006 had a CLTV (combined loan to value ratio) of more than 80\%; $29 \%$ of originations in 2006 had a CLTV of more than $90 \% .44$

Residential real estate being a large fraction of the total assets of households together with the fact that households can and do use real estate as collateral to borrow against implies that a perceived increase in household wealth will result in a large increase in aggregate consumption. That view is consistent with the estimates in equation (3): a $\$ 100$ increase in housing wealth is associated with a $\$ 8.40$ increase in consumption. In contrast there is hardly any increase in consumption due to increased stock market wealth. The corollary is that bursting of the housing price bubble will have a far severe adverse impact on consumption.

Recovering from a recession often involves households moving to another location so that the skills of agents in the economy are better matched to demands for those skills. However, the recovery will be made more difficult when the recession is associated with a collapse of housing prices. That is because moving involves selling the current home and using the equity released from that sale to buy another home in a different location. When the equity in the home has been lost, selling a home and moving becomes difficult. To understand why, consider a hypothetical open economy with two agents, a and b. Agent a lives and works in location A and b in location B. Each lives in a house valued at $\$ 100$ and a mortgage debt of $\$ 80$. There is an unanticipated technology shock that makes the skills of each agent not relevant in their respective locations. However, if $\mathrm{A}$ moves to B and B moves to A, they can maintain their productivity and their jobs. If the housing values remain the same, each can sell their house to the other (through an intermediary,) payoff the loan, take a new loan for the same amount, and move. Suppose, instead the housing values drop to $\$ 80$ and that the banks require a minimum equity of $20 \%$. In that case, if they cannot sell their houses - their equity has been wiped out. Because they cannot relocate, they cannot recover from the adverse impact of the technology shock. 


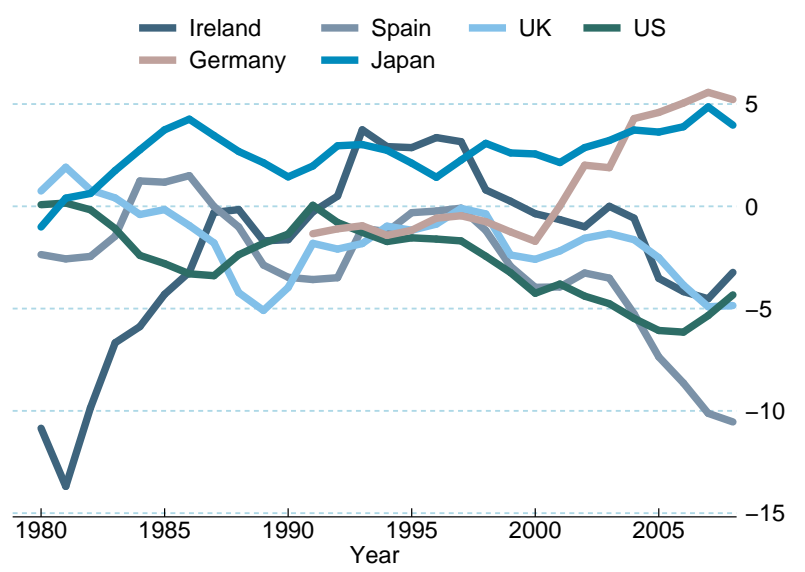

(a)

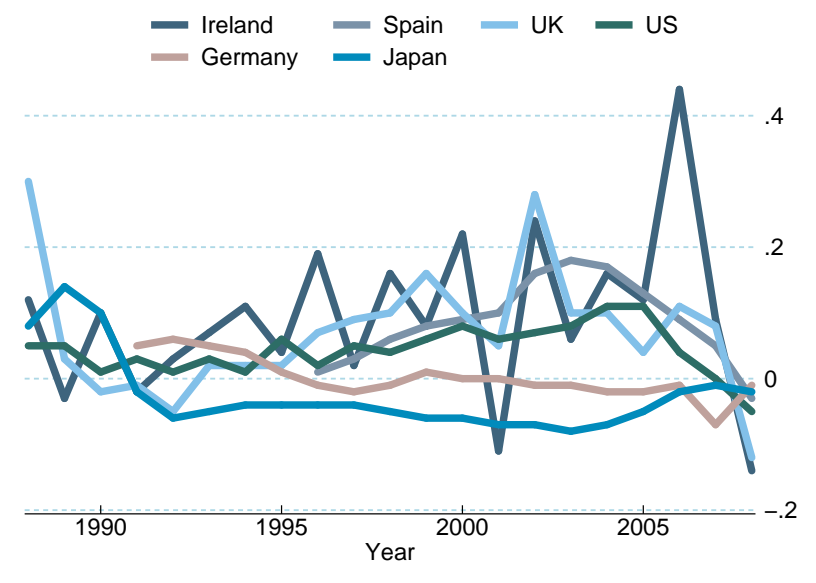

(b)

Figure 21: Panel a: Current account balances as percentage of GDP. Panel b: House price index, percentage change from previous year adjusted for consumer price inflation.

Source: OECD Economic Outlook 2008

\subsection{The US is not Alone: Some International Evidence}

A number of other developed countries experienced a period of current account imbalances and anemic personal savings rates similar to the US. Interestingly, many of these countries running significant CA deficits also have had a housing bubble and a subsequent crash. By contrast, CA surplus countries did not have housing price bubbles as illustrated by Germany and Japan in Figure 21. Similarly to the US, the countries that ran CA deficits will now face the task of stimulating their economies while credibly promising to impose the fiscal discipline down the road necessary to paying off their debts in the future. This will be the more challenging without the benefit of having the world's reserve currency at their disposal. The peripheral European countries will not have the option of simply printing money and, in the UK, the painful runs on the British pound in 1992 is still fresh in memory.

\section{Conclusion}

The common wisdom is that cheap money and lax supervision of financial institutions led to this financial crisis, and solving that crisis will take us out of the recession. We argue that the financial crisis was just the symptom. The fundamental cause of the crisis is the huge labor supply shock the world has experienced, that led to the glut in liquidity and money supply through the various channels discussed in this paper. Some have argued that global imbalances did not cause the increased leverage and the real estate bubble, but that they were important co-determinants. In our view, the need to accommodate the huge labor supply shock led to the economic policies followed by a number of countries in the 2000s that caused the distortions described by Obstfeld

\footnotetext{
${ }^{43}$ Cf. Bucks, Kennickell \& Moore (2006)

${ }^{44}$ Anatomy of a Credit Collapse, Confidential Kellogg Presentation, Amitabh Arora, December 2007.
} 
and Rogoff (2009) and others.

Our analysis suggests that for recovery to take place the structural imbalances in global capital flows need correction, in part through policy and institutional changes that promote higher saving in developed countries and capital flows into developing nations. Policies that promote households' understanding of the burden of the public debt in the US and European countries would contribute to higher national savings rates. The value of the US dollar may have to decline substantially, or the wages of Chinese workers engaged in export related activities will have to rise sharply, and alternative reserve currencies may have to emerge to stop the flood of capital into the US. As we have argued, it is not sustainable to have the demand for dollar reserves grow much faster than the US economy indefinitely as the US accounts for a smaller and smaller share of the world economy in the future.

The macro forces triggered by the labor shock is like a tidal wave that needed to wash ashore no matter what. History might have taken an entirely different path with better risk management controls in place in the US but then again, financial innovation might just have found a different way of getting highly leveraged deals done off-shore or through creative accounting 45 However, none of these macroeconomic considerations negate the need for the development of improved risk management in the broadest sense in order to ensure financial stability and prosperity going forward.

The return home of millions of World War II veterans increased the US labor force of about 60 million workers by almost $25 \%$ within a very short period of time. At that time the Department of Labor, which certainly had no cause to accentuate the negative, predicted that 12 to 15 million workers would be unemployed 46 That did not happen! That problem was managed well leading to prosperity instead of doom, thanks in no small part to the GI Bill and other governmental fiscal intervention. We believe that our analysis provides some new insights regarding the causes of the recession that will be helpful in managing this crisis well. The housing bubble created the illusion of wealth. In 2007 residential real estate was 1.45 times GDP. Suppose housing values have to drop by $25 \%$ to reach their fundamental levels of value. The impact on consumption given our estimate of $8.4 \%$ as being the wealth effect will be $1.45 \times 0.25 \times 0.084=3 \%$. The economy should be able to recover from there and move on its normal growth path with the right policies in place. For example, in the US, institutions that allow households to reduce their debt burden without going through a complex and lengthy bankruptcy process would promote relocation of resources and speed up economic recovery.

China and India will continue to need to bring tens of millions of rural laborers into the productive workforce in the coming decades and the world economy must find a sustainable way of dealing with this influx. As China's rapid rate of growth continues, its export led growth strategy of the past cannot go on indefinitely and China's domestic consumption will eventually have to

\footnotetext{
${ }^{45}$ Reminiscent of when Regulation Q gave rise to the Euro dollar market in the 1970s, or how a wide array of investment vehicles are not covered in the Basel II risk accounting.

${ }^{46}$ Richard Severo and Lewis Milford (1989), Sweet Wine At Last, The Quarterly Journal of Military History, Winter 1989.
} 
grow as a share of GDP. At the same time, Western economies will necessarily have to adjust to a new equilibrium in which commodities are scarcer and households face stiffer competition for jobs. In the new equilibrium the world will have hundreds of millions of new "middle class" citizens with increased appetites for consumption of commodities and use of scarce natural resources. As a result, not only exchange rates, but also relative prices must be allowed to adjust accordingly, benefitting those countries who see their terms of trade improve. 


\section{References}

Bernanke, B. (2005), Remarks at the homer jones lecture, Technical report, St. Louis, Missouri.

Bingxi, S. \& Lijuan, Y. (2009), Development of consumer credit in china, in 'Household debt: implications for monetary policy and financial stability'.

Bucks, B. K., Kennickell, A. B. \& Moore, K. B. (2006), 'Recent changes in u.s. family finances: Evidence from the 2001 and 2004 survey of consumer finances', Federal Reserve Bulletin 92(February), pp. A1-A38.

Dooley, M. P., Folkerts-Landau, D. \& Garber, P. (2007), Direct Investment, Rising Real Wages and the Absorption of Excess Labor in the Periphery, University of Chicago Press, pp. 103-132. URL: http://www.nber.org/chapters/c0125

Favilukis, J., Ludvigson, S. C. \& Nieuwerburgh, S. V. (2010), The macroeconomic effects of housing wealth, housing finance, and limited risk-sharing in general equilibrium, Working Paper 15988, National Bureau of Economic Research.

Foote, C. L., Gerardi, K., Goette, L. \& Willen, P. (2008), Subprime facts: What (we think) we know about the subprime crisis and what we don't, Federal Reserve Bank of Boston Public Policy Discussion Paper 08-2.

Geanakoplos, J. (2009), 'The Leverage Cycle', SSRN eLibrary .

Gennaioli, N., Shleifer, A. \& Vishny, R. W. (2010), 'Financial Innovation and Financial Fragility', SSRN eLibrary.

Graham, E. M. \& Wada, E. (2002), Foreign direct investment in china: Effects on growth and economic performance, Working Paper 01-03, Institute for International Economics, Washington DC.

Ludvigson, S., Steindel, C., \& Lettau, M. (May 2002), 'Monetary policy transmission through the consumption-wealth channel', FRBNY Economic Policy Review .

Palumbo, M. G. \& Parker, J. A. (2009), The integrated financial and real system of national accounts for the united states: Does it presage the financial crisis?, Working paper, Kellogg School of Management, Northwestern University.

Piazzesi, M. \& Schneider, M. (2009), 'Momentum traders in the housing market: Survey evidence and a search model', American Economic Review 99(2), 406-11.

Pozsar, Z., Adrian, T., Ashcraft, A. B. \& Boesky, H. (2010), 'Shadow Banking', SSRN eLibrary .

Shimek, L. M. \& Wen, Y. (2008), 'Why do chinese households save so much?', International Economic Trends (Aug).

URL: http://econpapers.repec.org/RePEc:fip:fedlie:y:2008:i:aug

Sussman, N. \& Yafeh, Y. (2011), 'Prudential policy, macroeconomic stability and comovement: The financial crisis in historical perspective', Hebrew University Manuscript . 
von Hayek, F. A. (1932), 'A note on the development of the doctrine of "forced savings"', The Quarterly Journal of Economics 47(1), pp. 123-133.

von Hayek, F. A. (1934), 'Capital and industrial fluctuations', Econometrica 2(2), pp. 152-167.

URL: http://www.jstor.org/stable/1906898

Wallison, P. J. \& Calomiris, C. W. (2009), 'The last trillion-dollar commitment: The destruction of fannie mae and freddie mac', The Journal of Structured Finance 15(1), pp. 71-80.

Wolff, E. N. (June 2007), Trends in household wealth in the united states: Rising debt and the middle-class squeeze, Working paper, New York University. 


\section{A Tables}

Table 1: Selected mortgage characteristics of US owner occupied residential housing. Source: US Census Bureau National Housing Survey.

Total Occupied Units (Thousands)

Panel A: Mortgages Currently on Property ${ }^{1}$

None, owned free and clear

Reverse mortgage

Regular and/or home-equity mortgage ${ }^{2}$ Regular mortgage

Home-equity lump-sum mortgage

Home-equity line of credit

Line of credit not reported, no regular or lump sum

Panel B: Number of Regular Mortgages and Home-Equity Mortgages

1 mortgage

$>2$ mortgages

Number not reported

Panel C: Payment Plan of Primary Mortgage

Fixed payment, self-amortizing

Adjustable rate mortgage

Other

Not reported

\section{Panel D: Payment Plan of Secondary Mortgage}

Units with two or more mortgages (Thousands)

Fixed payment, self-amortizing

Adjustable rate mortgage

Other

Not reported

\section{Panel E: Reason Primary Mortgage Refinanced}

Units with a refinanced primary mortgage ${ }^{2}$ (Thousands)

To get lower interest rate

To reduce the monthly payment

To increase payment period

To reduce payment period

To renew or extend a loan that has fallen due

To receive cash

Other reason

Panel F: Percent of Primary Mortgage Refinanced Cash Used for Home Additions, Improvements, or Repairs

Received refinance cash (Thousands)

Zero percent

1 to 99 percent

100 percent

Not reported

$\begin{array}{rrrrr}2001 & 2003 & 2005 & 2007 & 2009 \\ 71,708 & 72,238 & 74,931 & 75,647 & 76,428\end{array}$

$\begin{array}{rr}36 \% & 35 \% \\ 0 \% & 0 \% \\ 62 \% & 63 \% \\ 58 \% & 59 \% \\ 7 \% & 5 \% \\ 9 \% & 10 \% \\ 2 \% & 2 \%\end{array}$

$33 \%$
$0 \%$
$65 \%$
$60 \%$
$6 \%$
$13 \%$
$2 \%$

$33 \%$

$0 \%$

$64 \%$

$60 \%$

$5 \%$

$13 \%$

$2 \%$

$32 \%$

$0 \%$

$66 \%$

$61 \%$

$5 \%$

$12 \%$

$2 \%$

\section{$45 \%$}

$13 \%$

$46 \%$

$12 \%$

$45 \%$
$16 \%$

$6 \%$

$44 \%$

$17 \%$

$7 \%$

$46 \%$

$15 \%$

$7 \%$

11,024
$80 \%$
$3 \%$
$12 \%$
$2 \%$
$14 \%$
$13 \%$
$0 \%$

$$
\begin{array}{r}
16,595 \\
90 \% \\
2 \% \\
12 \% \\
1 \% \\
12 \% \\
8 \% \\
0 \%
\end{array}
$$$$
17,685
$$

\footnotetext{
${ }^{1}$ Regular mortgages include all mortgages not classified as home-equity or reverse.
}

1,925
$41 \%$
$27 \%$
$24 \%$
$9 \%$

